\title{
Aid Scaling Up: \\ Do Wage Bill Ceilings Stand in the Way?
}

\author{
Annalisa Fedelino, Gerd Schwartz, and \\ Marijn Verhoeven
}





\title{
IMF Working Paper
}

Fiscal Affairs Department

\section{Aid Scaling Up: Do Wage Bill Ceilings Stand in the Way? \\ Prepared by Annalisa Fedelino, Gerd Schwartz, and Marijn Verhoeven ${ }^{1}$}

April 2006

\begin{abstract}
This Working Paper should not be reported as representing the views of the IMF. The views expressed in this Working Paper are those of the author(s) and do not necessarily represent those of the IMF or IMF policy. Working Papers describe research in progress by the author(s) and are published to elicit comments and to further debate.

This paper assesses whether the scaling up of aid and the resulting increase in government spending that is needed to meet the Millennium Development Goals (MDGs) would be hampered by wage bill ceilings that are often part of government programs supported by the IMF's Poverty Reduction and Growth Facility (PRGF). Based on country case studies for 2003-05, the paper suggests that, in the past, wage bill ceilings have not restricted the use of available donor funds. Yet the paper offers a number of suggestions for further enhancing the flexibility of wage bill conditionality in PRGF-supported programs to respond to higher aid flows that may result in the future.
\end{abstract}

JEL Classification Numbers: E62, F35, H53, J30, J31, J45, O19

Keywords: IMF conditionality; aid scaling up; wage bill; MDGs

Author(s) E-Mail Address: afedelino@imf.org; gschwartz@imf.org; mverhoeven@imf.org

\footnotetext{
${ }^{1}$ The authors are with the Expenditure Policy Division of the IMF's Fiscal Affairs Department. Taline Koranchelian contributed significantly to this paper, and Larry Cui and Martin Hommes provided excellent research support. Guidance, comments, and suggestions from Peter S. Heller, Simonetta Nardin, Shamsuddin Tareq, and other IMF colleagues in different departments helped shape this paper and our thinking on the issues discussed here. All remaining errors and omissions are our own.
} 


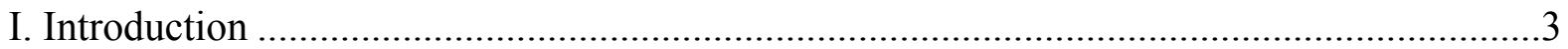

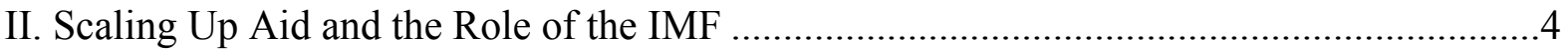

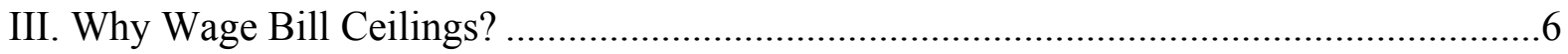

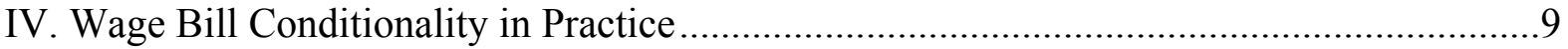

V. Do Wage Bill Ceilings Accommodate Donor-Financed Wage Spending in Priority

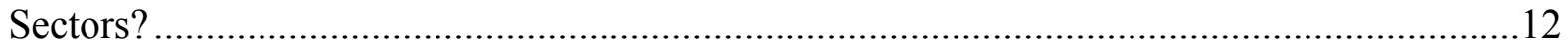

VI. Improving Wage Bill Conditionality ..................................................................... 16

Tables

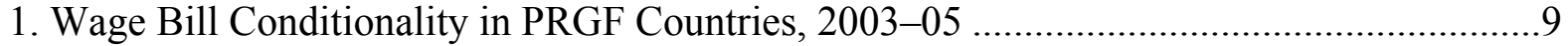

2. Coverage of Wage Bill Ceilings in PRGF Countries, 2003-05.....................................11

Figures

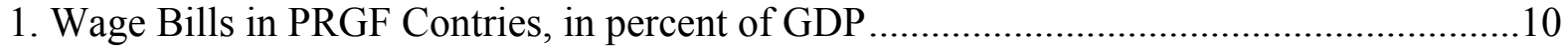

2. Wage Bills in PRGF Countries, in percent of total spending …......................................10

\section{Boxes}

1. Did IMF Policies Prevent the Hiring of Teachers in Zambia ...........................................

2. Overview of Terminology in PRGF-Supported Adjustment Programs .............................8

3. Escalation of Wage Bill Conditionality-Four Country Cases ........................................13

Appendices

1. List of Countries with PRGF-Supported Adjustment Programs, 2003-05........................18

2. Wage Bill Conditionality in PRGF-Supported Programs, 2003-05 ................................19

3. Structural Conditionality on Wage Bill Policy ..........................................................27

4. Overview of Wage Bill Trends ...................................................................................28

Appendix Tables

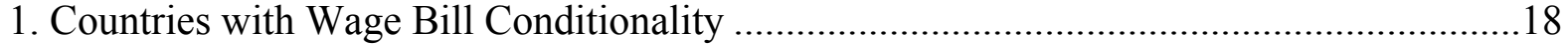

2. Countries without Wage Bill Conditionality ............................................................. 18

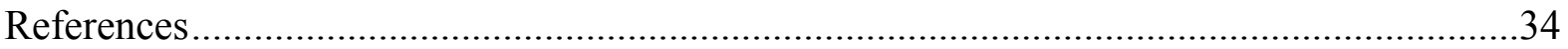




\section{INTRODUCTION}

Meeting the Millennium Development Goals (MDGs) requires both more government spending and better policies. The MDGs only stand a chance to be met if sectors that play key roles in reducing poverty are significantly strengthened. This usually calls for more, and sometimes much more government spending. For example, Mattina's (2006) estimates for Ethiopia show that the total cost of achieving the MDGs amounts to almost six times the country's current annual GDP. Roughly three-quarters of this would have to come in the form of additional public spending, financed by foreign aid. In per capita terms, aid to Ethiopia would need to be scaled up from around US\$11 in 2005 to over US\$65 by 2015. However, money alone will not be sufficient. Success in achieving the MDGs also requires country ownership of poverty-reducing strategies, effective sectoral policies, and skillful management of the macroeconomic challenges associated with sizable aid flows.

Many countries face shortages of trained personnel in specific key sectors, like health and education. Often, these human resource constraints are major impediments to implementing social policies, be it in combating HIV/AIDS or increasing primary school enrollment (Chen and others, 2004, and World Bank and IMF, 2005). Employment shortfalls are especially large in Sub-Saharan Africa, where estimates suggest that meeting the MDGs will require a tripling of the health-sector labor force, or adding more than one million workers over time (Berg and Qureshi, 2005). ${ }^{2}$ Also, the larger number of better qualified workers will need to have the right incentives to work effectively, including financial incentives.

Overcoming these shortages is particularly challenging when the government has a high wage bill that has been a source of macroeconomic imbalances. Where this is the case, increasing wages and employment in shortage sectors without reforming wage and employment distortions in other sectors is usually not an option. As a result, many countries have responded to high government wage bills by establishing wage bill ceilings, often in conjunction with civil service reform in the context of an adjustment program supported by the IMF's Poverty Reduction and Growth Facility (PRGF). ${ }^{3}$

\footnotetext{
${ }^{2}$ Strengthening human resources would not in itself be sufficient to remove human resources bottlenecks for meeting the MDGs. Other steps include the need to increase complementary nonwage current spending in step with or ahead of new hiring and to address an inefficient distribution of human resources. South Africa, for example, had to ramp up nonwage current spending (e.g., for teaching materials) to enhance the efficiency of wage spending in education. In contrast, in Yemen, a key constraint is an inadequate supply of doctors and teachers in rural high-poverty areas, which raises the issue of whether sufficient financial incentives can be offered for workers to relocate. Financial incentives are also key to retaining qualified staff. For instance, recent newspaper articles have pointed to the emigration of qualified nurses from Sub-Saharan Africa to developed countries like the United Kingdom (e.g., http://www.cnn.com/2004/WORLD/africa/08/03/nurses.uk/index.html and http://news.bbc.co.uk/1/hi/health/3083041.stm).

${ }^{3}$ Appendix I lists the countries with Poverty Reduction and Growth Facilities (PRGFs) during 2003-05. The PRGF is an IMF lending facility under which loans are extended to PRGF-eligible LICs in support of their poverty reduction strategies (International Monetary Fund, 2005a).
} 
In this paper, we assess whether wage bill ceilings have been detrimental to hiring additional personnel in key social sectors when additional donor resources were available. Overall, the paper suggests that the two objectives - keeping the government wage bill under control and hiring additional workers paid by donor funds - are not at odds with each other, but do require a delicate balancing of policies. Our empirical investigation did not find that wage bill ceilings in IMF-supported programs have prevented expanding public employment in priority sectors when donor funds were made available. ${ }^{4}$ Yet more could be done to enhance the transparency of how additional donor funds for wage spending are being accommodated in wage bill ceilings in IMF-supported programs. This can only be successful, however, if the donors, on their part, provide clear indications about their plans to provide aid, including over the medium term. Also, recipient governments need to strengthen the policy dialogue between sectoral ministries and key macroeconomic policy agencies to address macroeconomic and sectoral absorption constraints and increase the flexibility and efficiency of wage spending to support fiscal sustainability.

The paper discusses these various issues in detail. The next section highlights the role of the IMF in helping countries meet the MDGs, including aid absorption in the context of wage bill ceilings. The rationale for wage bill ceilings in PRGF-supported programs is covered in Section III. Section IV turns to some empirical evidence, including the modalities for such conditionality in recent PRGF-supported programs. Some options for reconciling aid scaling up and wage bill conditionality are offered in Section V. Section VI concludes with points for further discussion.

\section{SCALING UP AID AND THE ROLE OF THE IMF}

The scaling up of aid needed to meet the MDGs has created new policy challenges. Most importantly, governments have to decide how best to allocate scaled-up donor resources, including for expanding service delivery in priority sectors like health and education.

In the short term, country capacities to absorb additional aid funds in key sectors are often limited. Since the pool of workers with the right skill mix is often small—particularly in countries that are hard hit by HIV/AIDS - alternative solutions are being sought. In education, a common approach has been to set new standards for certifying teachers that do not require a teaching degree. In health, a main strategy has been to leverage doctors and nurses better with community health workers, who are trained to provide primary and preventive health care services. The available evidence suggests that these strategies can be cost effective in facilitating a rapid scaling up of workers and/or improving social outcomes,

\footnotetext{
${ }^{4}$ This finding is in line with other empirical work. For example, a recent survey by the Center for Global Development (2005) drawing on 353 responses from health-sector professionals, did not find that restrictions related to IMF-supported programs impeded implementation of policies related to HIV/AIDS prevention, treatment, and care. While "IMF caps" were listed as a concern in only one percent of the responses, the five leading concerns were related to lack of political will (29 percent); poor national coordination ( 28 percent); shortcomings of the health care delivery system (14 percent); national absorptive capacity constraints (8 percent); and policy confusion (7 percent).
} 
although capacity constraints and questions about the quality of services remain (World Bank and IMF, 2005). Inadequate government policies represent another obstacle to an effective use of funds. For example, where patronage dominates government hiring, this may need to be addressed before employment can be expanded in an effective manner.

At the same time, the envisaged scaling up of aid and resulting increase in government spending also complicates macroeconomic management. ${ }^{5}$ Ultimately, for aid to have an impact on poverty and the MDGs, increased aid needs to result in a real transfer of resources to the recipient country - that is, larger net imports. But, insofar as the aid is not directly spent on imports, it adds to inflationary pressures on domestic goods and services, while not raising net imports enough. And, if left unchecked, such inflationary pressures could set back economic growth, and particularly hurt the poor. Effective macroeconomic management of scaled up aid inflows may require an appreciation of the real exchange rate to bring about the increase in net imports and ease domestic inflation (see, for example, IMF, 2005b).

Also, entering into longer-term spending commitments on the basis of historically volatile aid inflows raises concerns about fiscal sustainability and aid dependency. Decision making on staffing is more difficult when aid is volatile. In particular, a government's decision to hire additional staff or increase government wages to be financed by available aid funds would be difficult to reverse when such flows decline or dry out (Foster, 2004, and Heller, 2005). At the same time, increased reliance on foreign financing could lead to aid dependency and reduced incentives for strengthening domestic resource mobilization (Gupta and others, 2005).

In this overall context, IMF support aims at addressing the macroeconomic challenges associated with scaling up of aid and increased government spending. Specifically, IMF support, in the form of surveillance, technical assistance, and access to financing, is aimed at helping governments address development needs in a way that is consistent with macroeconomic stability. In this context, the IMF also advises governments on creating fiscal space through resource mobilization, reduction in unproductive spending, and noninflationary financing. It collaborates with other institutions, like the World Bank, in integrating into its policy advice key considerations outside its core area of expertise (e.g., sectoral policies in education and health).

Yet, the IMF's role in promoting MDG-related spending has been questioned; particularly, with respect to the conditionality included in PRGF-supported programs. The IMF has often been faulted for singularly focusing on the need to control fiscal deficits and denying

\footnotetext{
${ }^{5}$ Following the 2002 Monterrey conference, where donors committed to improving the level and quality of financial support to reach the MDGs, net Official Development Assistance (ODA) from OECD member states went up by 15 percent in real terms during 2001-04, reaching US\$80 billion in 2004. In 2005, net ODA is estimated to have increased by 23 percent in real terms, to US\$98 billion. Based on official promises, the OECD estimates that its member countries will increase net ODA through 2010 by a further 31 percent in real terms, to US\$128 billion (OECD-DAC, 2006).
} 
countries the budgetary flexibility needed to meet the MDGs. For example, it has been argued that ceilings on the government wage bill in PRGF-supported programs have stopped countries from using donor resources for expanding employment in poverty-reducing priority sectors (Box 1 provides an example). This debate is likely to intensify as the scaling up of aid accelerates in the years ahead. ${ }^{6}$

\section{Why Wage Bill Ceilings?}

The composition of spending matters. Individual spending components (including the wage bill) will determine the government's overall contribution to achieving growth and poverty reduction. They can also become important sources of macroeconomic volatility and pressures, for example, when high government wages and large employment push up the wage bill and crowd out other spending; when government wage increases feed into a general wage-price spiral that undermines competitiveness; or when wage increases result in fiscal slippages. Whether or not the wage bill creates macroeconomic concerns depends on many factors. For example, where private sector wages follow public sector wages, public wage restraint is particularly important. Similarly, under a fixed exchange rate regime, the macroeconomic impact of large increases in public wages and employment are harder to absorb than under a floating regime. ${ }^{7}$

Some IMF-supported programs do include wage bill ceilings to complement other fiscal targets. ${ }^{8}$ For example, in Ghana, where wage spending had been a source of significant budget overruns, the government's PRGF-supported program included a performance criterion (PC) on the wage bill in $2005 .{ }^{9}$ The ceiling was established to support government efforts to bring wages under control, while a computerized payroll system for the public sector was being developed. Similarly, in Mozambique, concerns about a loss of fiscal control as a result of a ballooning wage bill led the government to introduce a quantitative benchmark on the wage bill in its PRGF-supported program in 2004. The benchmark aimed at focusing attention on factors underlying wage increases, and highlighted the need to link civil service hiring decisions to overall development objectives and comprehensive civil service reform. It also served to stress concerns about potential macroeconomic problems that could result from entering into long-term expenditure commitments without long-term donor commitments to finance them. Nicaragua agreed to the introduction of a PC on the wage bill against a background of public sector wages being well above comparable private

\footnotetext{
${ }^{6}$ The broader question of aid scaling up and PRGF program design is addressed in Gupta and others (2005), Heller (2005), and International Monetary Fund (2005a).

${ }^{7}$ The importance of public wage restraint under fixed exchange rates is reflected in the convergence criteria for the countries of the monetary union of West Africa (WAEMU), which stipulate that government wages should not exceed 35 percent of domestic fiscal revenues.

${ }^{8}$ For an overview on wage bill conditionality in PRGF-supported programs during 2003-05, see Appendix II.

${ }^{9}$ An overview of the terminology used in PRGF-supported programs is provided in Box 2.
} 


\section{Box 1. Did IMF Policies Prevent the Hiring of Teachers in Zambia?}

The Global Campaign for Education (CGE) issued a brief in 2004 entitled "Undervaluing Teachers: IMF Policies Squeeze Zambia's Education System." 1/ The brief claims that "to qualify for debt relief, Zambia has been forced to stop hiring the teachers and health workers it desperately needs" and that "last year, the Fund...told the government to reduce its public sector wage bill to no more than 8 percent of GDP. In order to achieve this, the Ministry of Finance not only had to withdraw long overdue wage increases, but it also had to ban any new hiring of teachers or health workers."

In a response, the IMF stated that "at no time have IMF policies prohibited the Zambian government from hiring new teachers or other priority workers such as doctors or nurses. In fact, the Fund has worked closely with the Zambian authorities to find solutions that allow for such hiring." 2/ The IMF made the following points:

- Up until 2004 Zambia's domestic debt and debt service costs were rising at unsustainable rates and severely cutting into resources available for poverty-reducing programs. The leading contributor to this unsustainable situation was the government wage bill, which increased from 5.3 percent of GDP in 2000 to 8.4 of GDP in 2003 , driven by large increases in wages and allowances.

- In April 2003, government wages were raised again, and a new housing allowance was introduced. These measures were not in the budget approved by parliament, and would have cost an additional $2 \frac{1}{2}$ percent of GDP. In July 2003, IMF staff and the authorities agreed that a wage bill of such size would jeopardize the economic recovery as it had to be financed through monetary expansion and additional government borrowing, which in turn would put undue pressure on prices and interest rates and squeeze priority spending.

- The large increase in government wages in 2003 was itself a constraint on hiring as some ministries found that their budget allocations did not provide enough room for recruiting new staff during the year. Also, savings from attrition of some 4,000 staff during the year were used for hiring in the central administration rather than in priority sectors.

- Structural factors have also been an obstacle to new hiring. In 2004, over 7,000 teachers were ready to take retirement, but the government could not afford paying termination benefits. Donors stepped in to resolve this; these teachers remained on the payroll, still receiving their salaries while not working, and the hiring of available newly qualified teachers was delayed.

- The 2004 PRGF-supported program did not include a limit on wage spending for teachers and health workers, while an earlier arrangement in 2002 included a freeze on civil service hiring that specifically exempted the hiring of teachers, doctors, and nurses from the freeze. ${ }^{3}$ Similarly, the wage bill ceiling under the present arrangement explicitly accommodates the hiring of new teachers and includes allocations for hiring of new frontline staff by the Ministry of Health.

Indeed, the budget for 2005 included extra resources to accommodate hiring of additional teachers and health workers, as a well as a retention scheme for nurses and clinical staff. By the end of 2005, the government had recruited an additional 8,000 teachers and 1,336 medical personnel. The proposed budget for 2006 moves in the same direction - the allocation to education and health is increased further to 45 percent of the discretionary budget from 36 percent in 2005 . This will allow the government to recruit an additional 4,578 teachers and 800 medical personnel.

1/ The CGE is a non-government organization that aims to "promote education as a basic human right" and "mobilizes public pressure on governments and the international community to fulfill their promises to provide free, compulsory public basic education for all people," see http://www.campaignforeducation.org/.

2/ Available at http://www.imf.org/external/np/vc/2004/111804.htm.

3/ See footnote 3 of Table 2 and paragraph 37 of the Technical Memorandum of Understanding available at http://www.imf.org/external/np/loi/2002/zmb/02/index.htm. 


\section{Box 2. Overview of Terminology in PRGF-Supported Adjustment Programs 1/}

Performance criteria (PCs) apply to clearly-specified variables or measures that can be objectively monitored and are so critical for the achievement of the program goals or monitoring implementation that disbursements under the arrangement should be interrupted in cases of non-observance.

- Quantitative PCs refer to variables that are reasonably under the authorities' direct or indirect control, and can be measured in a timely way. Typical quantitative PCs refer to foreign exchange reserves, monetary policy, fiscal policy, and external debt.

- Structural PCs refer to policy actions that are critical for the success of the program or for monitoring implementation, and should be defined unambiguously. They are in general limited to measures that are macro-critical.

Adjusters protect a program from relatively small deviations from program assumptions, such as shortfalls or delays in external financing or privatization receipts that could be accommodated within the program without affecting the program's main objectives. They are designed to ensure an appropriate balance between adjustment and financing in response to adverse shocks. Adjusters apply to quantitative PCs and not to benchmarks (see below).

Waivers for the nonobservance of PCs are supported by the staff and granted by the Board on the basis that: (i) the noncompliance is minor and does not affect significantly the program objectives; and

(ii) the deviation is self-correcting (temporary) or the authorities have taken the necessary measures to correct the deviation.

Structural benchmarks are used for measures that cannot be objectively or adequately monitored to be PCs, or for small steps in the overall reform process, that would not individually warrant an interruption of Fund financing in case of breach - they are a "lighter" form of conditionality than PCs. As they are less critical than PCs, adjusters do not apply to them. They can be set on numerical thresholds (quantitative benchmarks) or structural measures.

1/ Based on International Monetary Fund (2002).

sector wages, while the wage bill had grown rapidly to reach about $8 \frac{1}{2}$ percent of GDP at end-2005, at the high end for Latin American countries. The PC reflected concerns about the risk of a wage-price spiral that could undermine the country's external competitiveness.

Thus, in general, wage bill ceilings have been used to address concerns about wage bill dynamics and to support structural reforms of public sector employment and wages. Even when the level of government employment rather than the level of wages is the main issue of concern, wage bill ceilings may be used as a proxy, albeit an imperfect one, to control employment levels when reliable data on the latter are not available. ${ }^{10}$

Yet, wage bill ceilings usually provide only a short-term fix and ultimately need to be supplanted by civil service reform. Prolonged use of wage bill ceilings may lock in

\footnotetext{
${ }^{10}$ Non-PRGF Fund-supported arrangements have occasionally included conditionality on employment. For example, the current Stand-By Arrangement with Turkey includes limits on new hiring.
} 
inappropriate civil service structures unless combined with structural reforms to address inefficiencies of civil service employment and pay structures. Often, civil service reform is needed to address problems such as overly compressed wage scales; overstaffing (particularly, at lower levels of government); and ineffective promotion, transfer, hiring, and redundancy procedures. In addition, wage ceilings may create incentives to increase nonwage compensation, such as housing allowances and other in-kind benefits. This happened, for example, in Mali, as the country sought to comply with the WAEMU wage bill criteria. ${ }^{11}$ The resulting fragmentation of civil servant remuneration and the proliferation of allowances and benefits obscured the true level of wage-related spending, encouraged inequities in compensation, and reduced the overall transparency of such spending.

\section{Wage Bill Conditionality in Practice}

How common are wage bill ceilings in PRGF-supported programs? Overall, between 2003 and 2005, some conditionality on the wage bill was in place in half of the 42 countries with PRGF-supported arrangements (Table 1). Quantitative PCs were usually introduced in countries with a relatively high wage bill that had been increasing relative to GDP and total spending (Figures 1 and 2); ${ }^{12}$ frequently, the goal of such PCs was to limit further growth in the wage bill rather than lowering the level of wage spending. More specifically:

- $\quad$ Frequency. About 40 percent of the PRGF-supported programs included quantitative conditionality on the overall wage bill. Eight had a PC limiting the overall wage

Table 1. Wage Bill Conditionality in PRGF Countries, 2003-05

\begin{tabular}{|c|c|c|c|c|c|c|c|c|}
\hline & (1) & $(2)=(5)+(6)+(7)$ & \multirow{2}{*}{\multicolumn{2}{|c|}{$\begin{array}{c}(3)=(5)+(7) \\
\text { Quantitative } \\
\text { Conditionality }\end{array}$}} & $(4)=(6)+(7)$ & (5) & (6) & (7) \\
\hline & \multirow[t]{2}{*}{$\begin{array}{c}\text { Countries with } \\
\text { PRGFs }\end{array}$} & \multirow{2}{*}{$\begin{array}{l}\text { Countries with } \\
\text { Wage Bill } \\
\text { Conditionality }\end{array}$} & & & \multirow[t]{2}{*}{$\begin{array}{c}\text { Structural } \\
\text { Conditionality }\end{array}$} & \multirow{2}{*}{$\begin{array}{c}\text { Quantitative } \\
\text { Conditionality } \\
\text { only }\end{array}$} & \multirow{2}{*}{$\begin{array}{c}\text { Structural } \\
\text { Conditionality } \\
\text { only }\end{array}$} & \multirow{2}{*}{$\begin{array}{c}\text { Quantitative and } \\
\text { Structural } \\
\text { Conditionality }\end{array}$} \\
\hline & & & $\mathrm{PC}$ & $\overline{\text { Benchmark }}$ & & & & \\
\hline Africa & 24 & 14 & 4 & 9 & 8 & 6 & 1 & 7 \\
\hline Asia & 6 & 1 & 0 & 0 & 1 & 0 & 1 & 0 \\
\hline Europe & 1 & 0 & 0 & 0 & 0 & 0 & 0 & 0 \\
\hline \multicolumn{9}{|l|}{ Middle East and Central } \\
\hline Asia & 7 & 2 & 0 & 0 & 2 & 0 & 2 & 0 \\
\hline Western Hemisphere & 4 & 4 & 4 & 0 & 2 & 2 & 0 & 2 \\
\hline Total number of countries & 42 & 21 & 8 & 9 & 13 & 8 & 4 & 9 \\
\hline
\end{tabular}

Source: Appendix II.

\footnotetext{
${ }^{11}$ In part as a result, Mali did not breach the WAEMU criterion on wages (see footnote 7).

${ }^{12}$ Average wage bills increased in seven of the eight countries with quantitative PCs; the exception is Dominica, where the wage bill declined from an average of 17 percent of GDP in 2000-02 to 14 percent of GDP in 2003-05.
} 
Figure 1. Wage Bills in PRGF Countries 1/ (in percent of GDP)

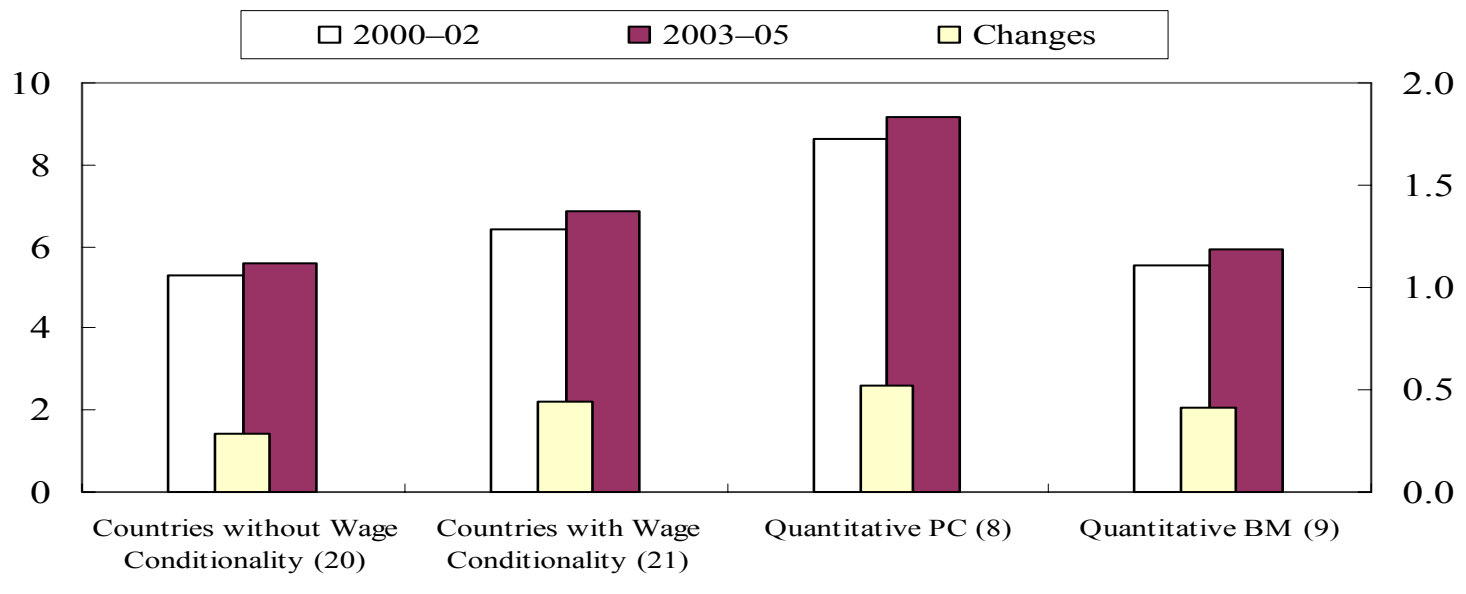

Source: Appendix IV.

1/ Changes are increases in 2003-05 from 2000-02, measured on the right axis. Sample size is shown in brackets. Data for Chad refer to wage bill in percent of non-oil GDP, and Mauritania is excluded because no wage data are available.

Figure 2. Wage Bills in PRGF Countries 1/

(in percent of total spending)

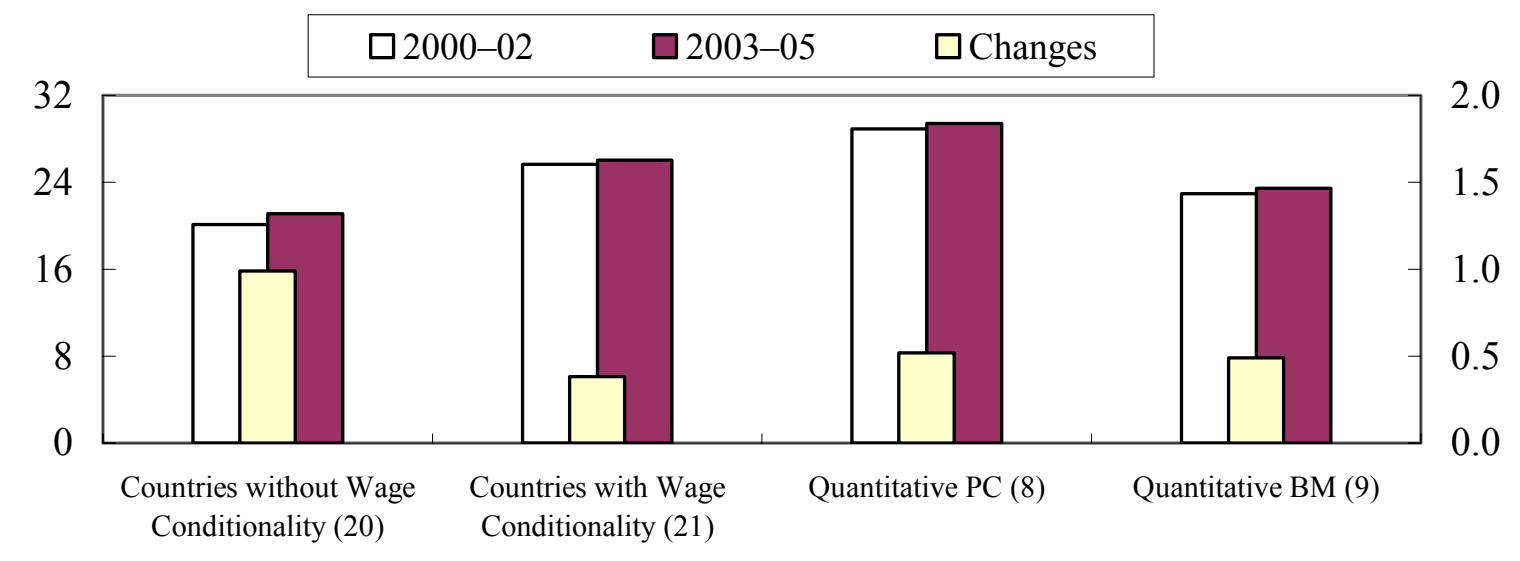

Source: Appendix IV.

$1 /$ Changes are increases in 2003-05 from 2000-02, measured on the right axis. Sample size is shown in brackets. Mauritania is excluded because no wage data are available. 
bill, ${ }^{13}$ and nine had a quantitative structural benchmark. ${ }^{14}$

- Distribution. Conditionality was geographically concentrated in Sub-Saharan Africa and Central America. In Sub-Saharan Africa, 13 PRGF-supported programs (out of 24) included quantitative conditionality on the wage bill - with PCs in four cases (Chad, Ghana, Kenya, and Malawi) and benchmarks in nine cases (Benin, Burkina Faso, Burundi, Mali, Mozambique, Niger, Senegal, Sierra Leone, and Zambia). In Central America and the Caribbean, all PRGF-supported programs had PCs on the wage bill (Dominica, Guyana, Honduras, and Nicaragua). In other regions (Asia, Europe, and Middle East and Central Asia, accounting for the remaining 14 PRGFs), PCs or benchmarks on the wage bill were not used. ${ }^{15}$ The regional distribution of wage bill ceilings in PRGF-supported programs reflects differences in the size of the government wage bill, which was significantly higher in Sub-Saharan Africa and Central America (7 percent of GDP on average during 2003-05) than elsewhere (4 percent of GDP).

- $\quad$ Coverage. Coverage of the wage bill varied across PRGF-supported programs (Table 2), but with a large concentration of targets on central government wage bills. In only one country, Guyana, did the coverage extend to the nonfinancial public sector. However, definitions varied across countries. For example, the targeted wage bill in Benin excluded salaries related to projects financed by foreign donors and

Table 2. Coverage of Wage Bill Ceilings in PRGF Countries, 2003-05

\begin{tabular}{|c|c|c|c|}
\hline & \multicolumn{3}{|c|}{ Coverage } \\
\hline & Central government & General government & $\begin{array}{l}\text { Non-financial } \\
\text { public sector }\end{array}$ \\
\hline Quantitative PCs & $\begin{array}{l}\text { Chad, Ghana, Kenya, } \\
\text { Malawi, Dominica, } \\
\text { Honduras, Nicaragua }\end{array}$ & & Guyana \\
\hline Quantitative benchmarks & $\begin{array}{c}\text { Burundi, Mozambique, } \\
\text { Niger, Sierra Leone, } \\
\text { Zambia }\end{array}$ & $\begin{array}{c}\text { Benin, Burkina Faso, } \\
\text { Mali, Senegal }\end{array}$ & \\
\hline Total & 12 & 4 & 1 \\
\hline
\end{tabular}

Source: Appendix II.

\footnotetext{
${ }^{13}$ As of May 2006, six active PRGFs include PCs on wage bill ceilings (Dominica, Ghana, Guyana, Honduras, Malawi, and Nicaragua). Two other PRGF-supported programs (Chad and Kenya) include such PCs, but are presently inactive and performance under these programs has not been assessed recently.

${ }^{14}$ A structural benchmark is a weaker form of conditionality than a PC. Specifically, if a benchmark is missed, no waiver is needed to continue disbursements under an IMF-supported program (see Box 2).

${ }^{15}$ Wage bill developments are also monitored in these countries. For example, in Tajikistan, the need to increase substantially the salaries of government workers in 2004 led to a discussion between the government and Fund staff about how to address these pressures.
} 
transfers to local governments for teacher salaries. In Mali, the 2001-03

PRGF-supported program ceiling excluded wages paid under externally funded projects and transfers to local communities for the payment of teachers' salaries; these were subsequently included in the definition of the wage bill monitored under the PRGF-supported program that went into effect in May 2004.

- Duration. Once introduced, wage bill ceilings have been there to stay. In none of the 17 PRGF-supported programs were wage bill ceilings in the form of quantitative PCs and benchmarks dropped during 2003-05. In fact, in two cases (Chad and Malawi) benchmarks were over time "elevated" to quantitative PCs; the reverse, "downgrading" a PC to benchmark, has not yet occurred. In three other cases (Ghana, Guyana, and Nicaragua), PCs were introduced during the course of a program (Box 3). The fact that wage bill ceilings are maintained may suggest that they provide a fix, but ultimately do not resolve the macroeconomic pressures they try to address. It also reflects the challenges of carrying out effective and lasting civil service reform, which only few countries have been able to implement successfully (Stevens and Teggemann, 2004).

- Quantitative versus structural conditionality. The PRGF-supported programs in 13 of the sample countries included benchmarks on structural reforms to promote better wage and employment policies (Table 1, and Appendices II and III). In nine cases (seven in Sub-Saharan Africa and two in Central America), these qualitative benchmarks supplemented the wage bill ceilings, while four countries with structural conditionality (Democratic Republic of Congo, Azerbaijan, Tajikistan, and Nepal) did not have wage bill ceilings.

\section{Do Wage Bill Ceilings Accommodate Donor-Financed Wage Spending in PRIORITY SECTORS?}

How have wage bill ceilings accommodated donor-financed expansions of employment and pay in priority sectors? There are two sides to this question. First, do wage bill ceilings, at the time when they are set, take account of expected disbursements of aid for hiring additional personnel or increasing wages? This is a question of ex-ante accommodation. Second, can and do wage bill ceilings, once established, accommodate unexpected increases?

Accommodation is relatively easy when future increases in aid are known with certainty. PRGF-supported programs are designed to be consistent with poverty reduction strategies and use the latest estimates of available aid funding and the need for additional hiring and wage increases. In other words, wage bill ceilings usually reflect all available information on expected changes in foreign aid for hiring as set out in the government's poverty reduction strategy. For example, in Senegal, a quantitative benchmark on wage bill ceilings was introduced mainly to contain the growth in current spending. Nonetheless, the ceilings allowed for a 20 percent increase in the number of civil servants during 2003-05, in 


\section{Box 3. Escalation of Wage Bill Conditionality-Four Country Cases}

In five countries, PCs on the wage bill were introduced (Ghana, Guyana, and Nicaragua) or quantitative conditionality was made stricter during the course of a program or moving toward a new PRGF-supported program (respectively, in Chad and Malawi). Four of these cases are described below.

Ghana-From no conditionality to a PC on the wage bill. Wage spending overruns are a long-standing problem in Ghana, resulting in excessive domestic borrowing and distorted expenditure allocations, with the wage bill rising quickly during 2000-05 (Appendix IV). Under the 2003-06 PRGF-supported program, the authorities targeted an increase of wage spending (to 9 percent of GDP); overruns have taken place on two occasions, due to unbudgeted salary increases for some 30,000 staff in the education sector and unbudgeted base wage payments of subsidized agencies. To prevent further overruns, in 2005 the government committed to strengthening payroll management, including through computerizing its employee records. In addition, the 2005 program established a quantitative PC on the wage bill including all allowances. The ceiling allowed for an increase in wage spending to 9.1 percent of GDP from 8.5 percent of GDP in 2004, mainly to encourage capacity building and higher productivity by attracting and retaining qualified personnel. Over the medium term, the government committed to undertake a comprehensive civil service reform to address employment and wage issues. This reform is expected to reduce the wage bill to around 8.5 percent of GDP over time, thereby creating fiscal space for other high-priority spending programs.

Nicaragua-From no conditionality to a PC on the wage bill. In recent years, public sector wages have grown rapidly, approaching about $81 / 2$ percent of GDP in 2005 (at the high end of the distribution for Latin America) and reaching just over $1 / 3$ of total expenditure in 2005 (Appendix IV). Available data suggest that public wages have also risen well above private sector wages, which has risked setting off a wage-price spiral that could undermine competitiveness. The authorities have decided to adopt several measures to keep the wage bill in check, including lowering compensation growth and eliminating vacancies in a number of government agencies. In December 2005, they also agreed to introduce a new quantitative PC on the wage bill under the PRGF-supported program to keep its dynamics under control; according to the 2006 budget, wages will grow somewhat above inflation. This PC was introduced recently and it is too early to assess its impact.

Chad-From benchmarks to a PC on the wage bill. While the size of the wage bill was not unduly large (Appendix IV), the ceiling introduced under the 2000-04 PRGF-supported government program was meant to underpin improvements in civil service payroll management, which was seen as key to supporting the administrative decentralization process. The 2005-08 PRGF-supported program elevated the quantitative benchmark on the wage bill to a quantitative PC, reflecting the rise in the wage bill as a share of non-oil GDP and prospective changes in the payment system for the army, from the current lump-sum salary payment system to a wage scale based on seniority and grade. In 2005 , the wage bill was projected to rise by some $8 \frac{1}{2}$ percent, reflecting recruitment in priority sectors (out of an estimated 2,931 new hires, 2,625 were to be in the priority sectors) and implementation of the military wage scale (with a reduction of supplementary allowances). In addition, structural conditionality included the creation of a payroll and civil service roster.

Malawi-PC on the wage bill with a new PRGF program. In 2004, the authorities implemented a civil service wage reform that marked a significant improvement in transparency, by consolidating the previously untaxed numerous allowances (e.g., fuel and housing) into basic pay; unifying pay grades across the core civil service; reducing the number of grades to 18 from 75 ; and realigning and decompressing the pay line. This resulted in a 25 percent increase in gross wages and a 50 percent increase in the minimum wage, while pay to top-tier contractuals was frozen. However, the reform turned out to be significantly more costly than anticipated, resulting in a cost overrun of $1 \frac{1}{2}$ percent of GDP a year; the reform also increased significantly pension benefits. In these circumstances, a quantitative PC on the wage bill was introduced in the new 2005-08 PRGF program to underpin the authorities' intention to keep the domestically financed wage bill at or below 8 percent of GDP over the medium term. However, the cap includes an adjuster for wage spending funded under the health SWAp. This measure would help stem excessive wage drift, contain the impact of the October 2004 wage reform, and support a broader reform of the civil service compensation system aimed at to streamlining wages and salaries and improving management of government employees. 
line with employment levels projected in the government's Poverty Reduction Strategy Paper (PRSP). Similarly, the wage bill ceiling in Zambia was set to accommodate additional hiring of new teachers as well as the hiring of new frontline staff by the Ministry of Health (Box 1). In Malawi, the macroeconomic framework for 2005-08 fully accommodates a planned substantial increase in resources for the health sector. Over the next five years, donor-financed purchases of pharmaceuticals and supplementary salaries for health workers are projected to be in the neighborhood of 18 percent of GDP. ${ }^{16}$

When increases in the level and timing of aid are uncertain, program reviews provide frequent occasions to adjust conditionality as warranted by changed circumstances. ${ }^{17}$ PCs are only set for the next program review, which is typically three to six months ahead. Targets for subsequent reviews are usually only indicative; these are revisited and revised as needed at the time of each program review. Since aid-financed hiring often takes time to be carried out, even after the timing and modalities of the additional aid have been clarified and the funds have been made available, there is usually sufficient time to revise program conditionality to accommodate such hiring.

Also, wage bill ceilings may be designed from the outset not to stand in the way of future increases in the wage bill that occur for good reasons and/or in specific areas. More specifically, some PRGF-supported programs have included an explicit wage bill adjuster that comes into force when certain events occur. Alternatively, some PRGF-supported programs have defined the relevant wage bill to exclude specific sectors, or levels of government where donor-funded hiring was to take place.

The first option, an explicit adjuster, provides some conditional automaticity. An explicit adjuster would be defined to increase the wage bill ceiling - defined according to a baseline assumption on available donor funds - to accommodate additional hiring or wage increases in specific sectors (e.g., education or health) if additional donor funds over and above the baseline become available. At the same time, the ceiling could be adjusted downward by the amount that donor funds fall short of the baseline; ${ }^{18}$ this would avoid loosening conditionality (e.g., by permitting the wage bill outside of priority sectors to increase) if the baseline donor funds for specific priority sectors do not materialize. The maximum allowed adjustment (upward or downward) could also be capped, if required by program objectives. For instance, an upward adjuster for donor-financed hiring in the health sector could be capped at levels that do not risk setting off a wage-price spiral.

\footnotetext{
${ }^{16}$ Wage developments in PRGF countries are shown in charts in Appendix IV.

17 The term "program review" refers to a periodic reassessment (often quarterly) of actual macroeconomic performance vis-à-vis projections and the parameters of the program. During a program review, the macroeconomic projections are updated, and the program parameters are revised as needed to take into account the latest projections.

${ }^{18}$ In principle, the adjuster could also be asymmetric, that is, accommodate aid inflows that are larger than anticipated, while not lowering the ceiling in case of disbursement delays.
} 
Explicit adjusters are not without problems. In particular, explicit adjusters can only be implemented effectively if they are well specified, and if there is a clear and monitorable link between donor funds and wage spending. Such a link may not always exist. But even when it does, the fact that PRGF-supported programs are reviewed frequently reduces the need for explicit adjusters, particularly when unexpected aid increases between reviews are fairly small.

Hence, explicit adjusters have not often been used. Of eight PRGF-supported programs with a quantitative PC on the wage bill, only the arrangement with Malawi includes an explicit adjuster. The adjuster allows for additional wage spending when wage-related disbursements under the multidonor Sector Wide Approach (SWAp) arrangement for the health sector are larger than expected; moreover, the adjuster is symmetric and without caps (that is, any funding increase above the program baseline is automatically accommodated). As the program with Malawi was approved in August 2005, the first review under the program has not yet been completed. Preliminary information suggests that SWAp disbursements have lagged behind the baseline projections, implying that the wage bill ceiling may need to be adjusted downward.

The second option - limiting the coverage of the targeted wage bill ceiling - may be used to exclude specific sectors or levels of government from conditionality. This would imply that increases in wages or employment in these sectors or levels of government, regardless of how they are financed (i.e., either foreign or domestic), are not subject to the program's ceilings. This option clearly entails risks. As the purpose of a wage bill ceiling is to control spending pressures (and ultimately macroeconomic risks) arising from government wages and employment, excluding large parts of the wage bill from the ceiling would reduce its effectiveness, particularly since partial ceilings are easier to circumvent than comprehensive ones. In addition, timely data on the distribution of the wage bill (particularly, across sectors)—needed for monitoring a limited ceiling — are often not available.

Yet, wage bill ceilings with limited coverage have been used extensively. For several PRGFsupported programs in our sample, the wage bill ceiling either excluded specific sectors or specific entities with foreign-financed employment (Table 2). This does not always reflect deliberate efforts to exclude priority sectors from wage bill ceilings (as was the case in the 2002 PRGF-supported arrangement with Zambia discussed in Box 1), but rather data limitations in many cases.

Even if a wage bill ceiling were to be breached, it would not necessarily disrupt the PRGFsupported program if it had occurred for good reasons. In particular, if a program review determines that a breach has occurred, the IMF's Executive Board may grant a waiver when this was warranted by circumstances. ${ }^{19}$ Waivers are by no means automatic, and relying on receiving a waiver could be a risky proposition for a borrowing country. At the same time, a

\footnotetext{
${ }^{19}$ A waiver is only needed when a PC is breached, not when another target, like a benchmark, is not observed.
} 
waiver does allow a program to continue without interruption. In the programs in our sample, however, all PCs on the wage bill were met, and no waivers were needed. The PCs were met in Dominica, Guyana, and Honduras. Wage bill PCs were introduced only recently in Chad, Ghana, Malawi, Nicaragua, and have not yet been subject to Executive Board review.

\section{Improving WAGe BiLl Conditionality}

Recent experience suggests that wage bill ceilings have not restricted the use of available donor funds, but the evidence falls short of conclusive proof. However, as donor funding for hiring in specific sectors is set to increase, for example in the context of expanding vertical programs,${ }^{20}$ the potential tensions arising from aid scaling up in the presence of wage bill ceilings may become more acute.

Lack of predictability and transparency of future aid flows remain main obstacles to devising effective wage bill conditionality in PRGF-supported programs. For example, in practice it is usually quite difficult to find out precisely how aid scaling up is to take place. Aid volatility and uncertainty hamper effective budgeting and have made ministries of finance more reluctant to precommit to funding additional priority spending needs and increasing aid dependency.

How then can the flexibility of wage bill conditionality in PRGF-supported programs be enhanced to respond to higher aid flows? Coordinated efforts by all parties involved are needed:

- $\quad$ From the IMF's side, program documentation should link explicitly the projections of donor support to the wage bill ceilings. Similarly, a clear connection between wage bill ceilings and the country's poverty-reduction strategy should be discussed with the authorities and reported in PRGF program documents.

- $\quad$ From the government's side, effective collaboration and exchange of information between agencies in charge of hiring (i.e., sectoral or line ministries) and the agencies in charge of budgetary and macroeconomic policy management (i.e., the ministries of finance) is critical. More generally, recipient governments should promote greater coordination with aid donors.

- $\quad$ From the donors' side, aid disbursements should be less volatile and more predictable, and disbursement schedules should be shared with recipient governments to enhance coordination and allow better budgetary planning and execution.

\footnotetext{
${ }^{20}$ Vertical programs are multidonor funds that focus on a specific health issue, such as HIV/AIDS. Examples include the World Bank's Multicountry AIDS Program (MAP); the Global Fund to Fight AIDS, Tuberculosis, and Malaria; and the U.S. President's Emergency Plan for AIDS Relief (PEPFAR).
} 
These efforts would promote greater overall consistency between the formulation and implementation of the government's poverty-reduction strategy and the government budget, and enable wage bill conditionality established under a PRGF-supported program to achieve its principal objectives.

While wage bill conditionality can be strengthened, the ultimate goal should be to make it redundant as a government policy tool. It is striking that, in our sample, we find no examples where wage bill PCs were phased out, against five countries where PCs were introduced (Box 3). This can be attributed to the difficulties in carrying out lasting structural reform, particularly civil service reform, which would make wage bill ceilings superfluous. Consideration should be given to phasing out wage bill ceilings when economic circumstances change. For example, for countries exiting from their volatile post-conflict environments, it may be possible to replace a ceiling on wage spending with more sophisticated conditionality (e.g., on civil service reform), or to drop conditionality altogether. In Mozambique, for example, which has successfully moved beyond the post-conflict environment under which the wage bill ceilings were initially established, this is currently being considered by the government.

Although the transparency and flexibility of wage bill conditionality can be improved, a scaling up of aid for wage spending may still raise concerns about macroeconomic stability and fiscal sustainability. In addition, foreign financing for wage spending raises specific issues that need to be addressed, including the mismatch between the length of time for which donor resources are committed (at most several years) and the more lasting implications of decisions to expand the number of workers or increase government pay. Possible solutions would include extending the period for which donors commit their resources; and establishing reserves to smooth the impact of aid volatility (Foster, 2004). Countries could also take measures to enhance the flexibility of their wage spending, for example, through expanded use of temporary and flexible contracts, contracting out of services, and concerted efforts to raise the efficiency of public service delivery (Davies, Gunnarsson, and Verhoeven, 2006). These measures would enhance countries' ability to adjust spending to changes in the level of available financing, thereby safeguarding fiscal sustainability. They would also help support a rolling back of aid dependency over time. 
List of Countries with PRGF-Supported Adjustment Programs, 2003-05

Appendix Table 1. Countries with Wage Bill Conditionality 1/

\begin{tabular}{llll}
\hline & APD & MCD & WHD \\
\hline BFR & Nepal & Azerbaijan & Chad \\
Burkina Faso & & Tajikistan & Dominica \\
Burundi & & Guyana \\
Congo, Dem. Rep. Of & & Honduras \\
Ghana & & Nicaragua \\
Kenya & & \\
Malawi & & \\
Mali & & \\
Mozambique & & \\
Niger & & \\
Senegal & & \\
Sierra Leone & & \\
Zambia & & \\
\hline
\end{tabular}

Appendix Table 2. Countries without Wage Bill Conditionality 1/

\begin{tabular}{|c|c|c|c|}
\hline AFR & APD & EUR & MCD \\
\hline Cambodia & Bangladesh & Albania & Armenia \\
\hline Cameroon & Lao People's Dem. Rep. & & Georgia \\
\hline Cape Verde & Mongolia & & Kyrgyz Republic \\
\hline Congo, Republic of & Sri Lanka & & Mauritania \\
\hline Ethiopia & & & Pakistan \\
\hline The Gambia & & & \\
\hline Lesotho & & & \\
\hline Madagascar & & & \\
\hline Rwanda & & & \\
\hline São Tomé \& Príncipe & & & \\
\hline Tanzania & & & \\
\hline Uganda & & & \\
\hline
\end{tabular}

1/ Regions are shown in columns and are defined according to IMF classification: AFR: Sub-Saharan Africa; APD: Asia Pacific; EUR: Europe; MCD: Middle East and Central Asia; WHD: Western Hemisphere. 


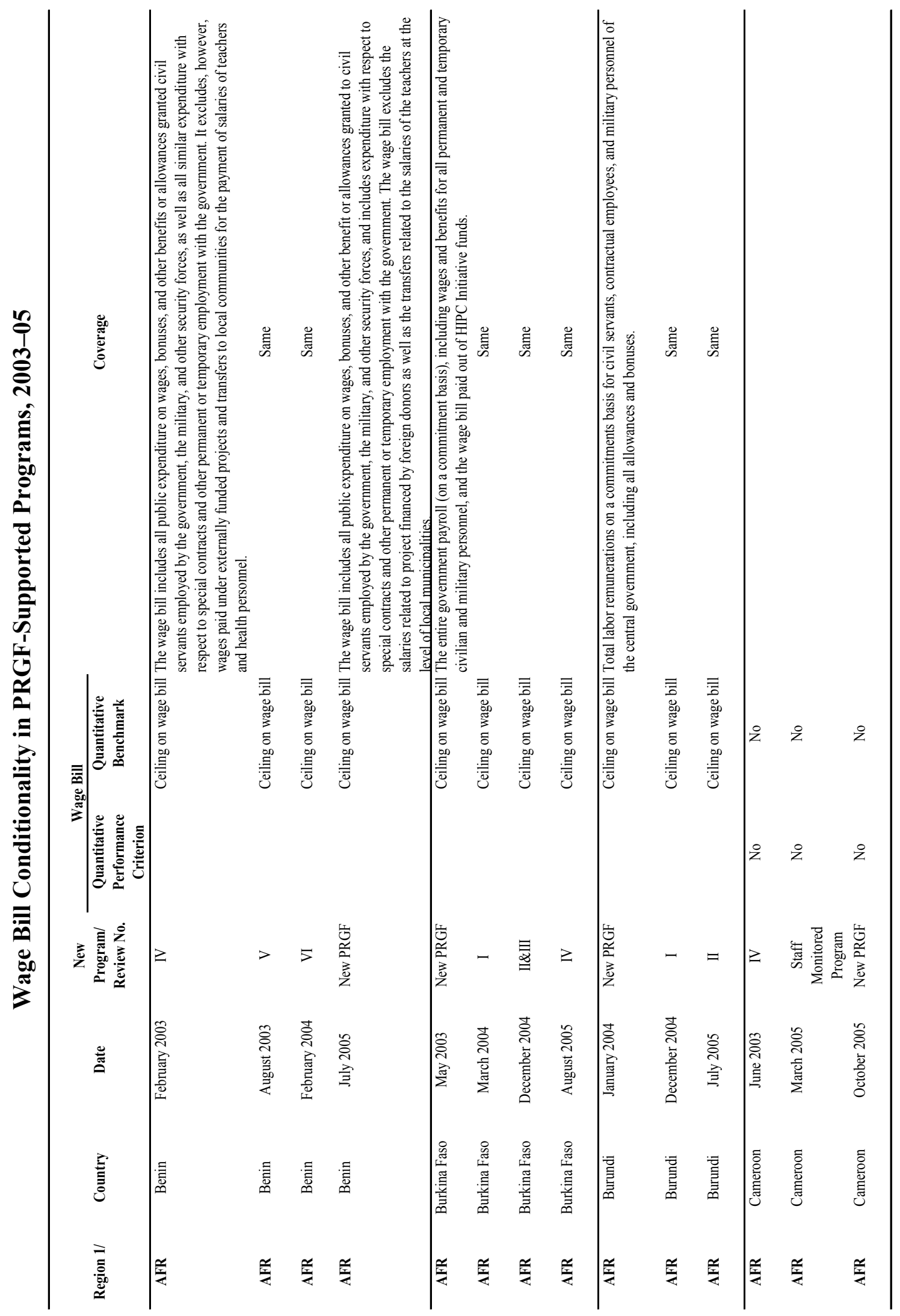




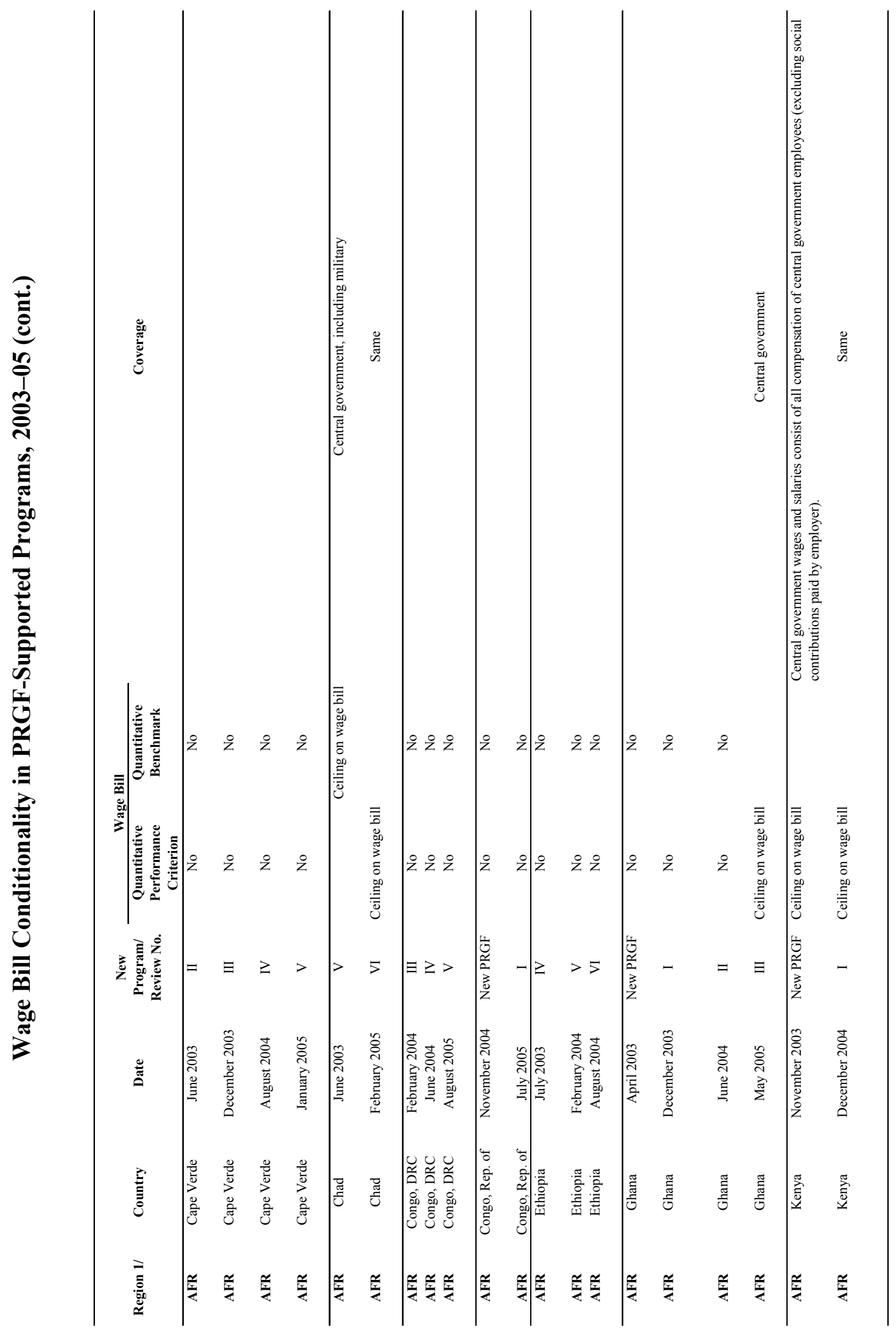




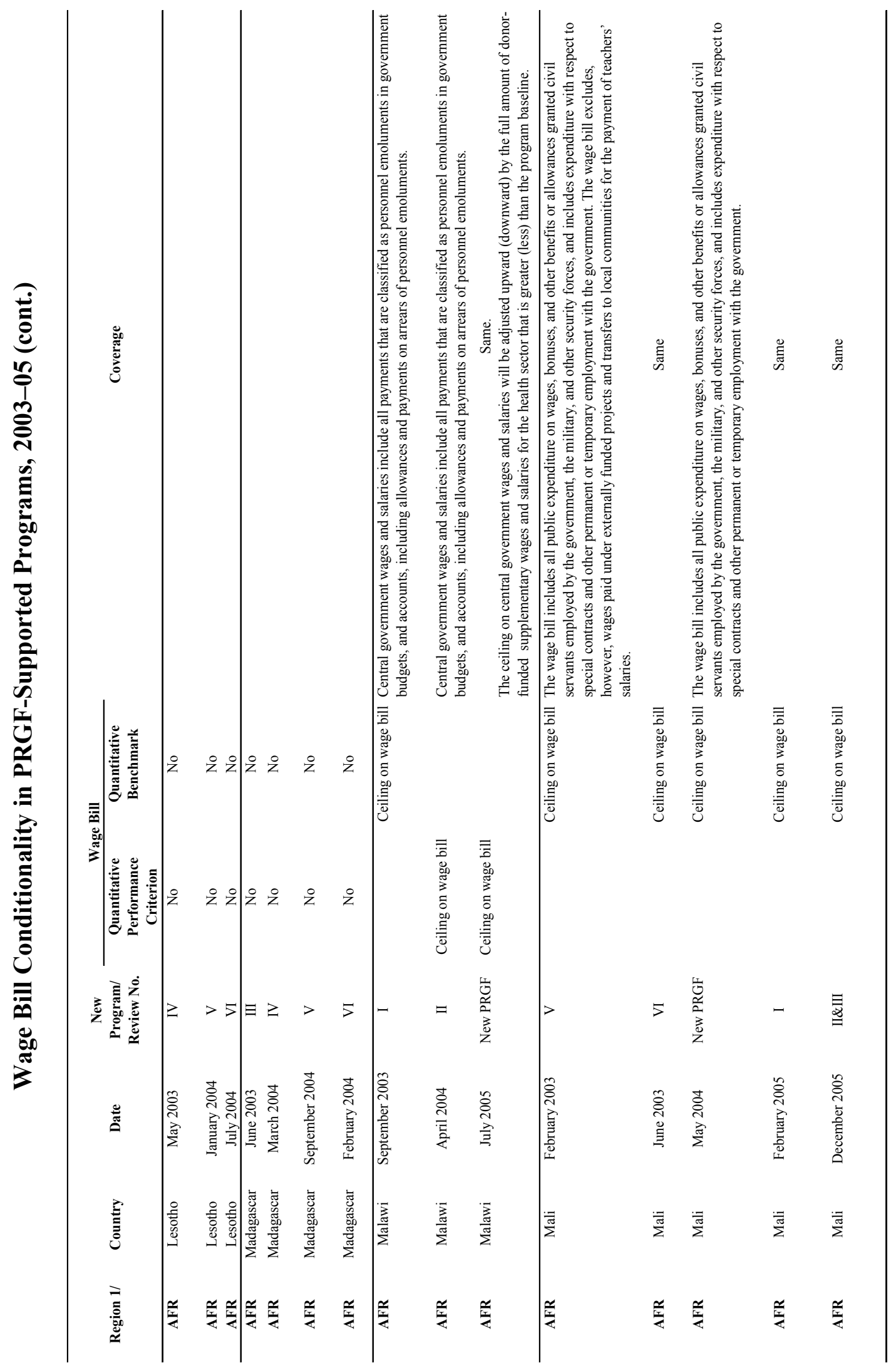




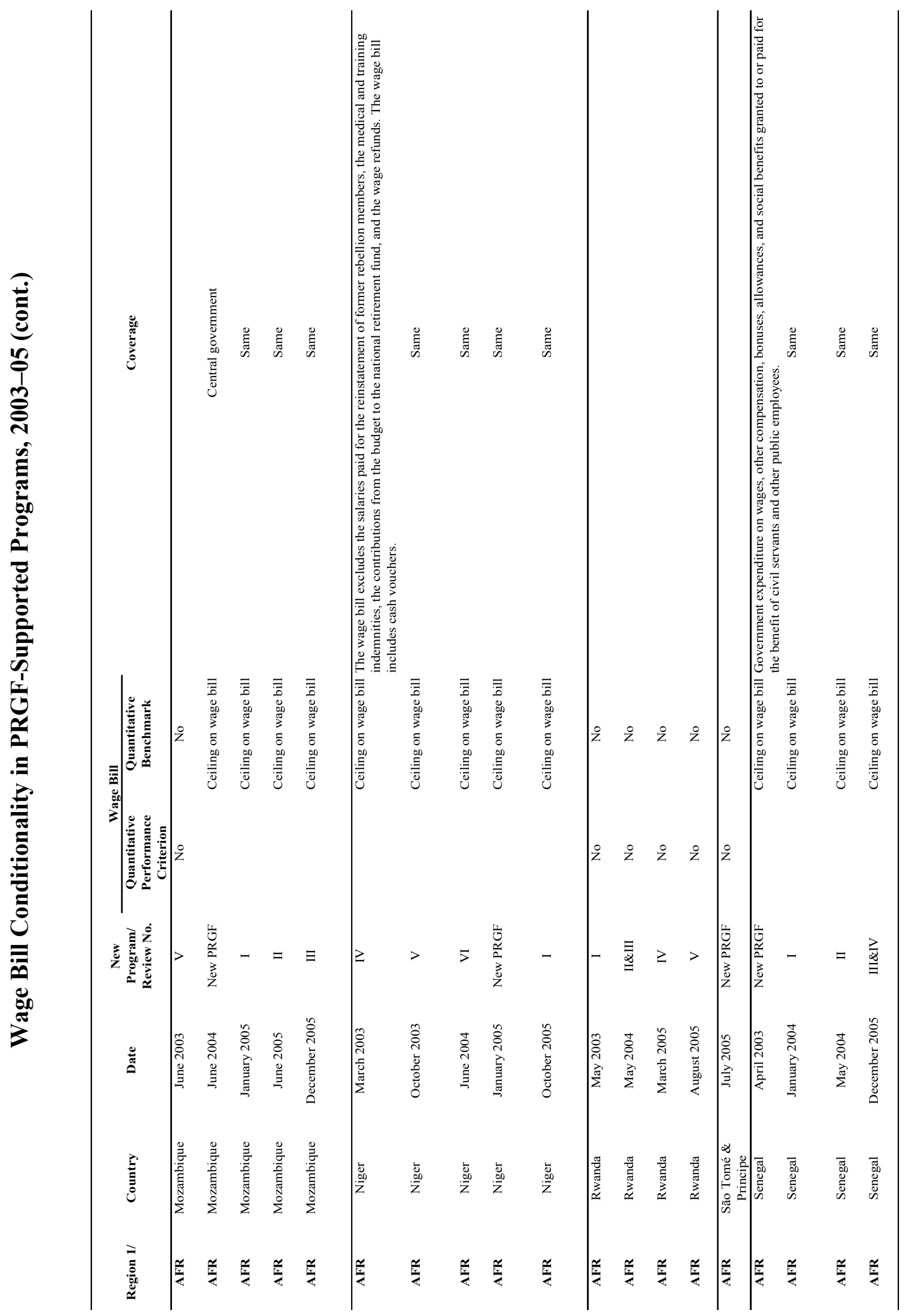




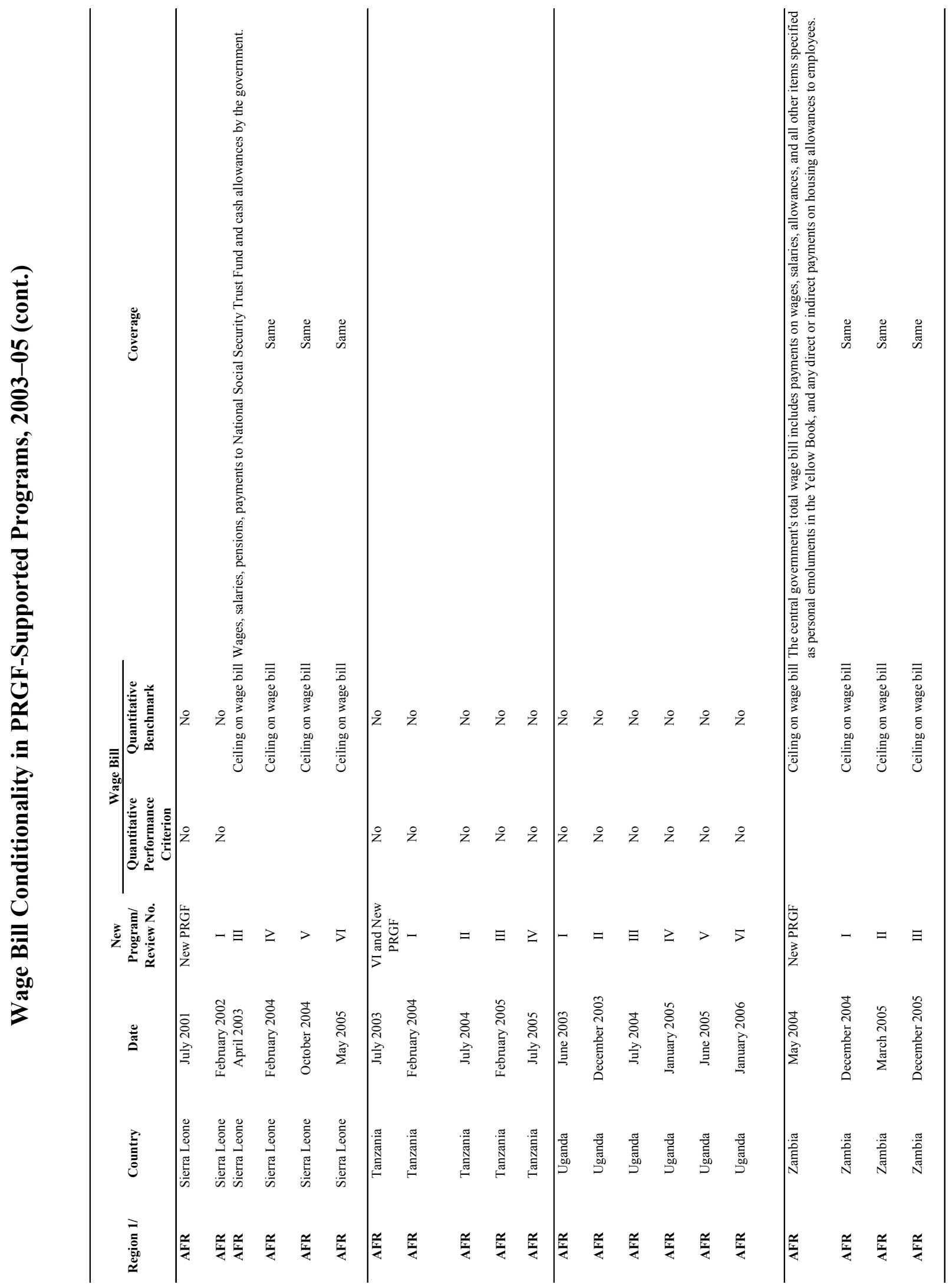









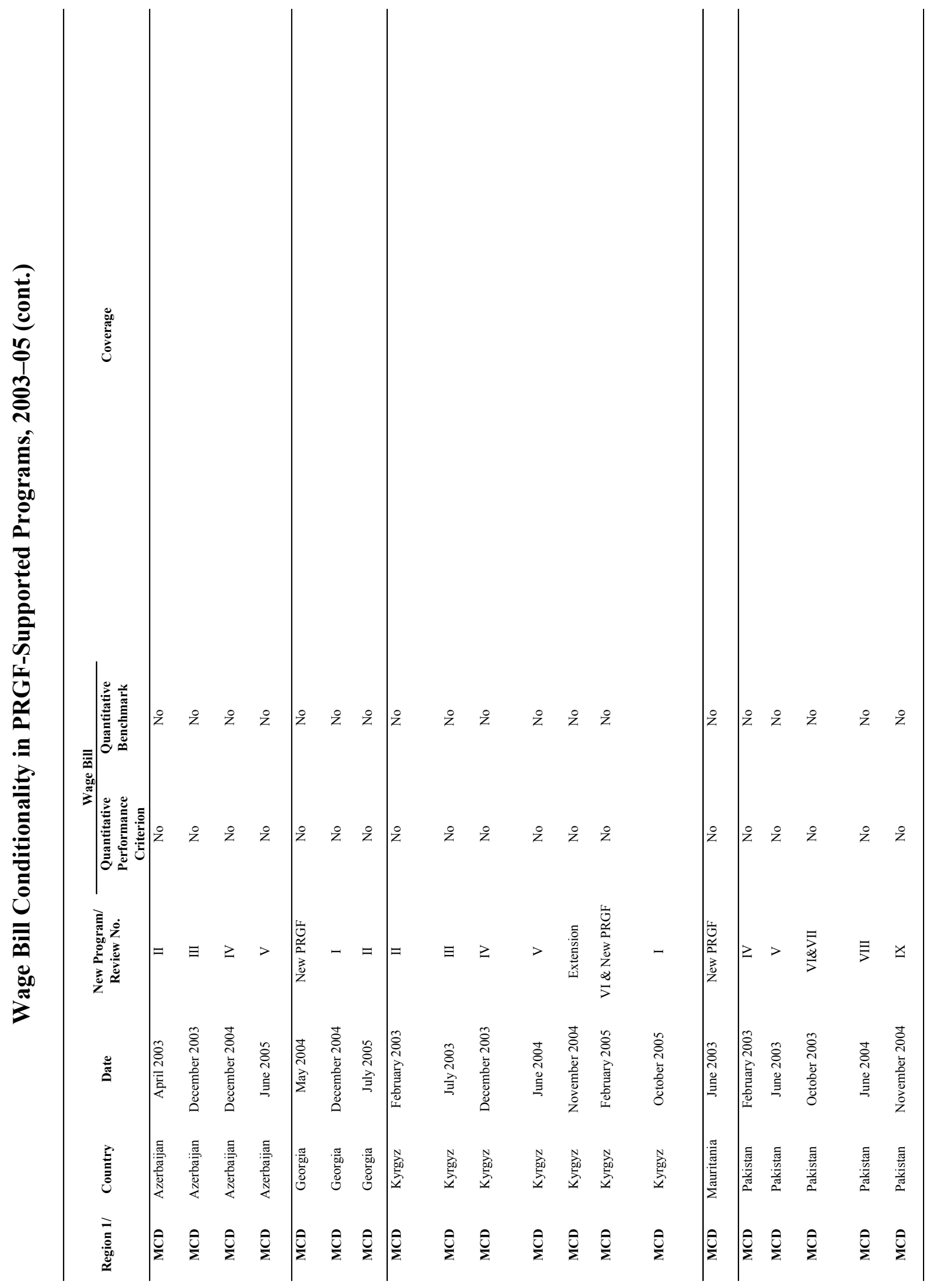




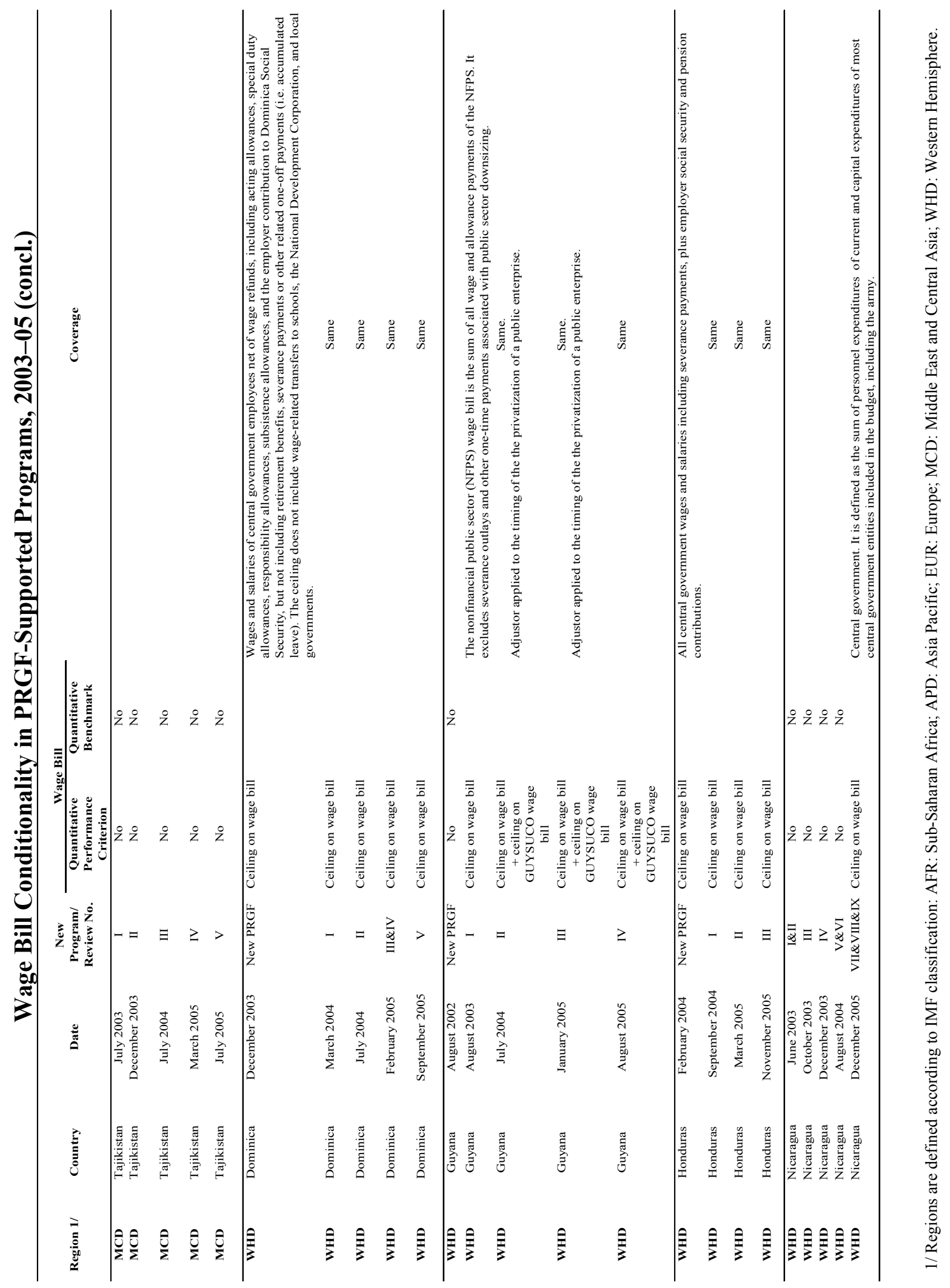




\section{Structural Conditionality on Wage Bill Policy}

PRGF-supported programs often rely on structural measures to strengthen wage bill policies, such as:

\section{Measures to improve payroll management}

- Develop a payroll and civil service roster based on a civil service census or update the registry of staff records (Chad). Complete a census of the wage bill for all budgetary sector employees (Albania).

- $\quad$ Transfer of the budgetary and administrative oversight on the pay, and transfer of paymasters to, the Treasury (Democratic Republic of Congo).

- $\quad$ Cabinet to approve the final plan for the civil service reform covering human resource policy, reviewing the organization and structure of the civil service and addressing wage policy and payroll management (Ghana).

- $\quad$ Establish public service remuneration board (Malawi).

- $\quad$ Completion of a financial audit of the wage bill (Niger).

- Introduce photo verification system for civil servants and teachers (Sierra Leone).

- Submission to cabinet of a timetable for the design of a comprehensive medium-term civil service reform (Azerbaijan).

\section{Measures to streamline the computation of wages}

- $\quad$ Determine new mechanism to determine salaries of public officials (Kenya).

- $\quad$ Consolidate all allowance into the salary structure (Malawi).

- $\quad$ Reorganize procedures for paying civil servants based on the recommendations of the external audit of the payroll system (Democratic Republic of Congo).

- $\quad$ Develop detailed schedule of wage adjustments by grade (Malawi).

- $\quad$ Issue regulations to integrate supplementary benefits into the overall salary (Honduras).

\section{Measures to rationalize employment levels}

- $\quad$ Eliminate identified ghost workers (Democratic Republic of Congo).

- Implement plan to eliminate vacancies (Nepal).

- $\quad$ Reduce the number of employees in the education sector by 5 percent (Tajikistan).

- $\quad$ Outline the process for reducing the wage bill by 5 percent through retrenchment (Dominica). 


\section{OVERVIEW OF WAge Bill TRends}

\section{PRGFs with Wage Bill Conditionality}
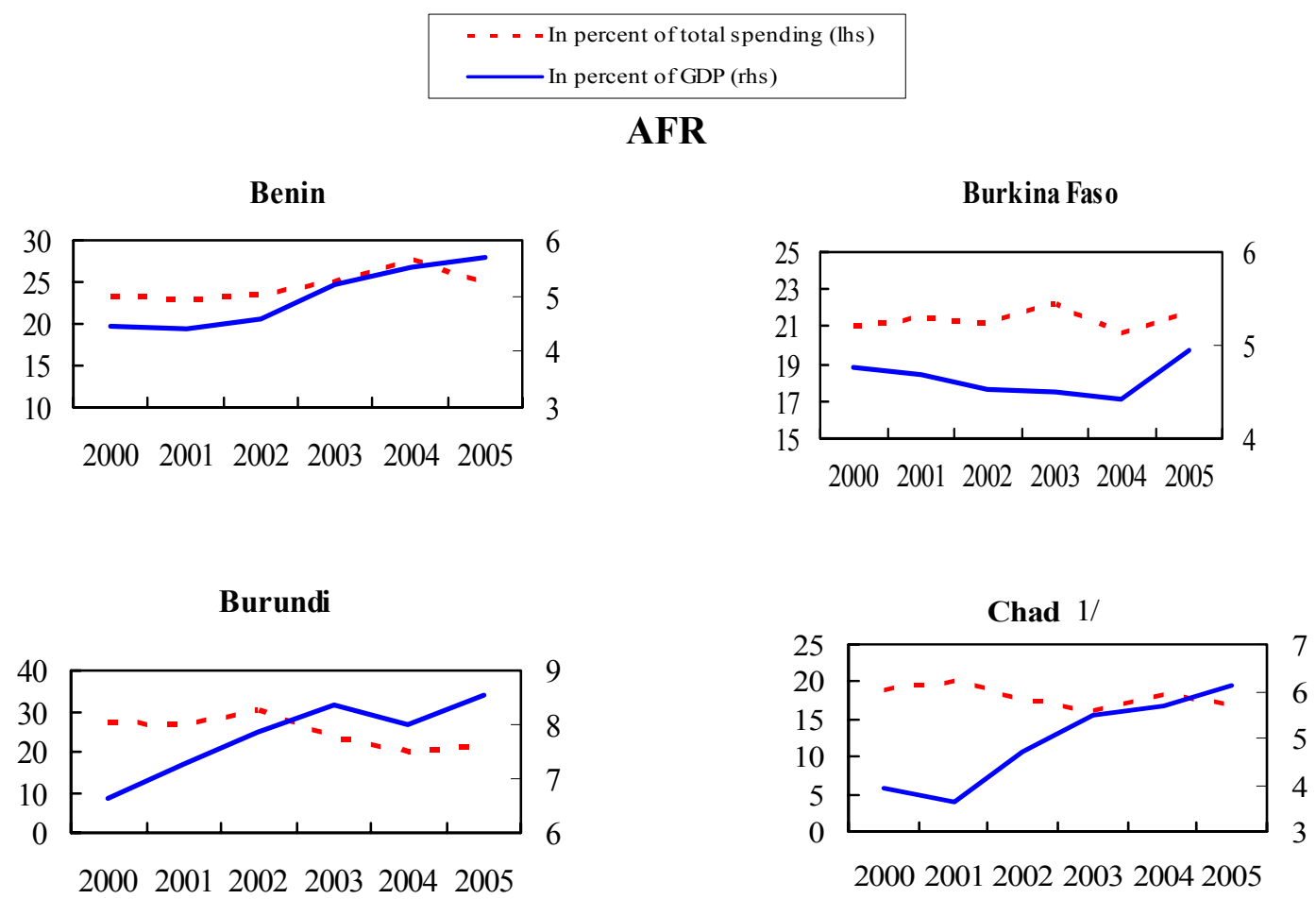

1 / Wage bill in percent of non-oil GDP is used.
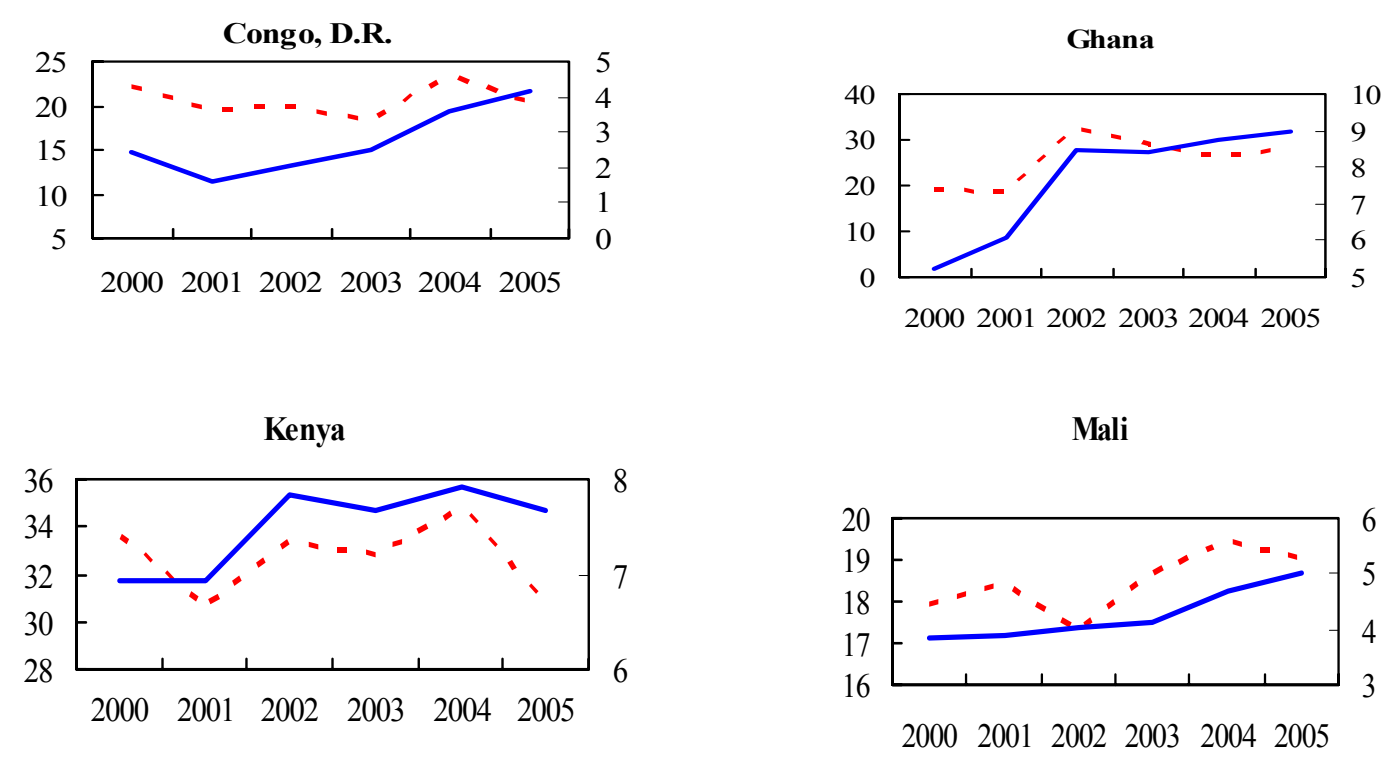

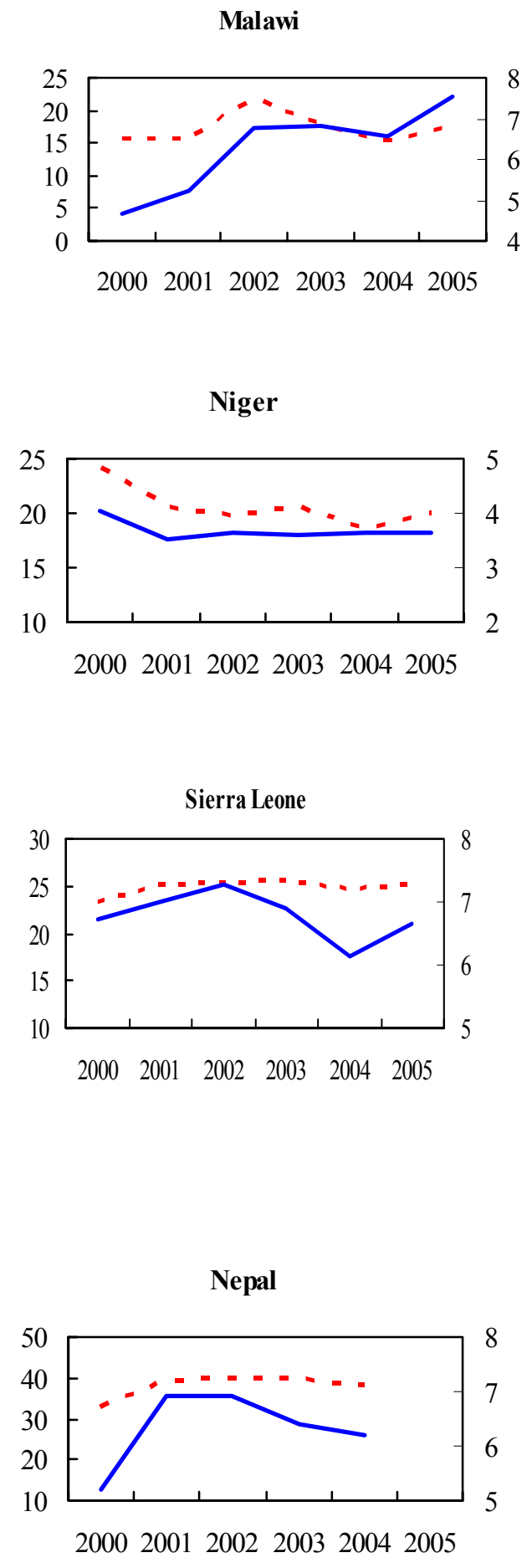
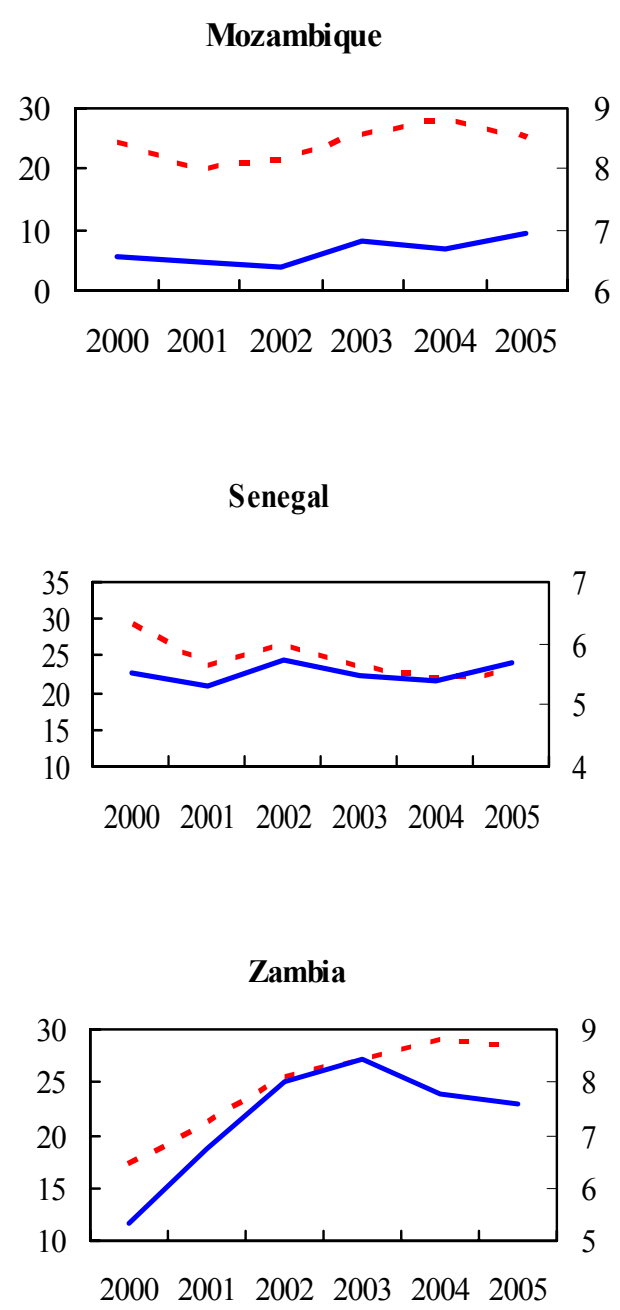

APD 
MCD

Azerbaijan

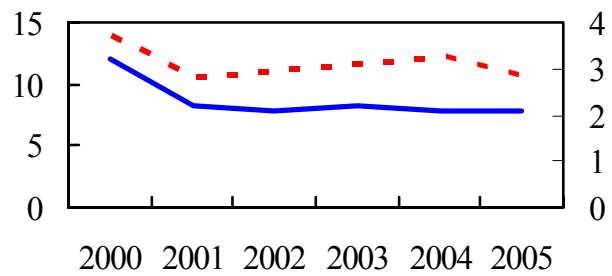

Tajikistan

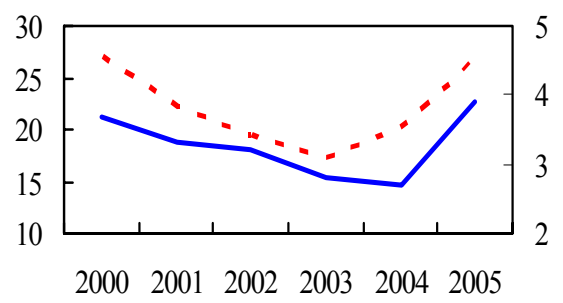

WHD

Dominica

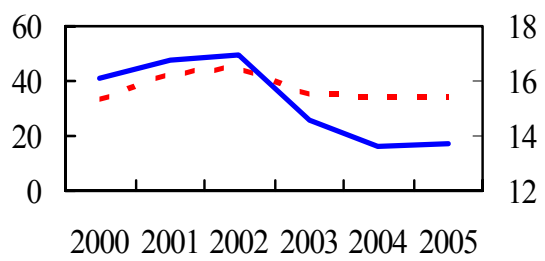

Honduras

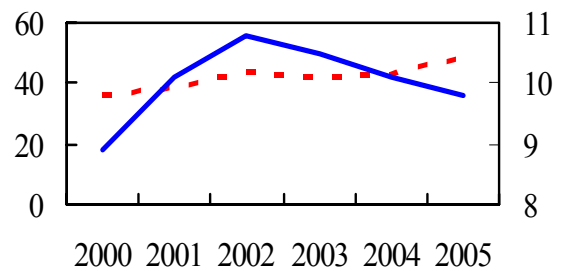

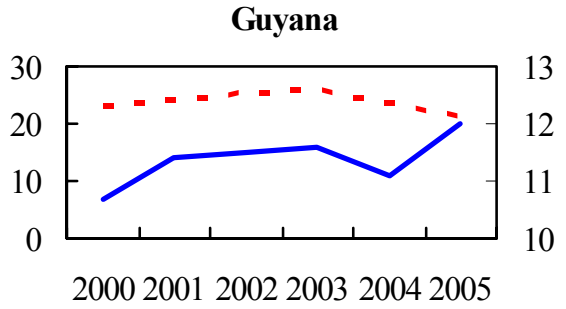

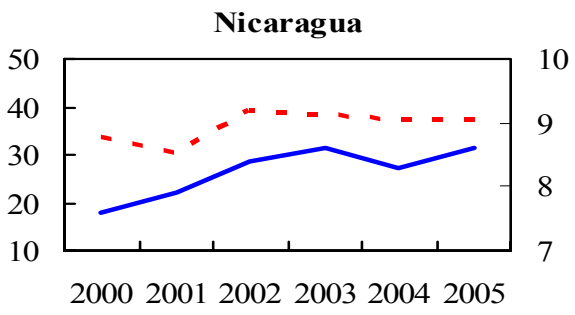




\section{PRGFs without Wage Bill Conditionality}

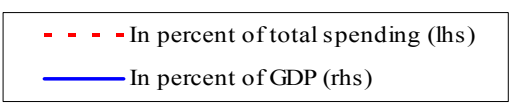

AFR

Cameroon

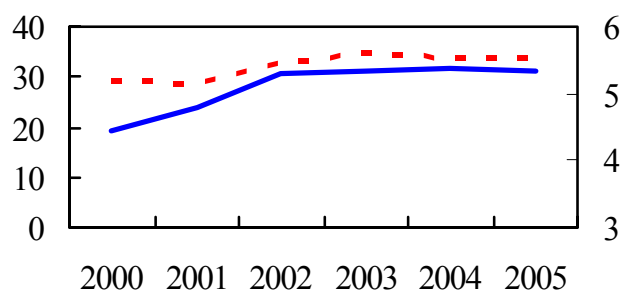

Congo, $\mathbf{R}$.

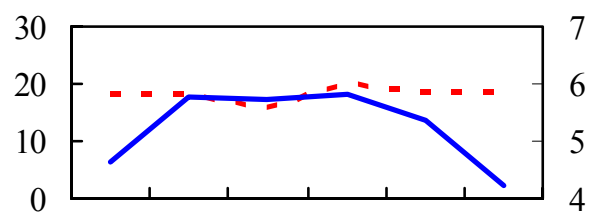

200020012002200320042005

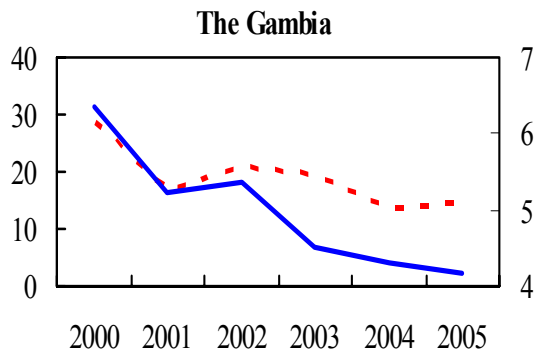

Madagascar



Cape Verde

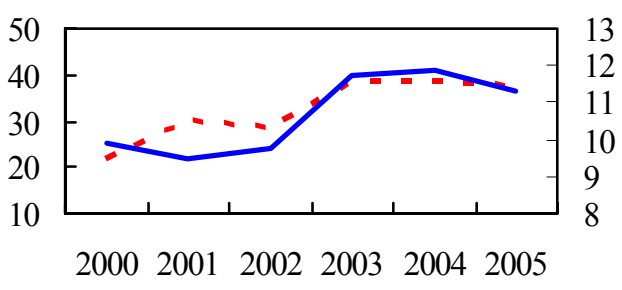

Ethiopia

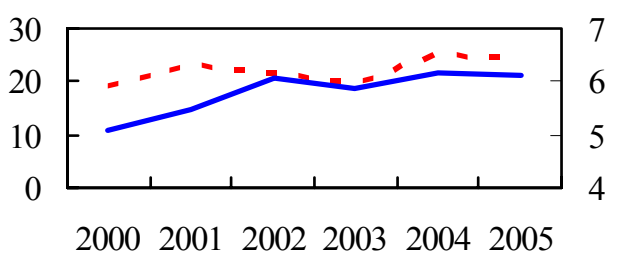

Lesotho

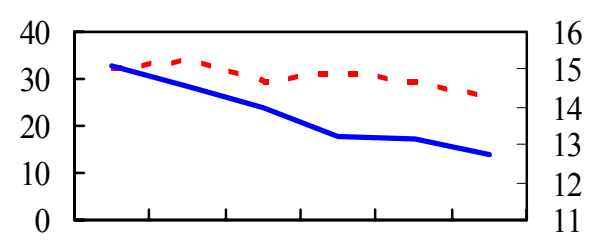

200020012002200320042005

Rwanda

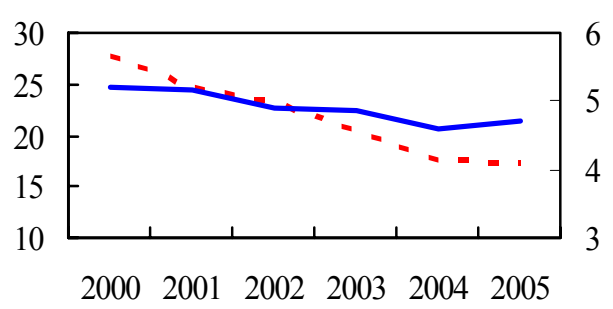


São Tomé \& Príncipe

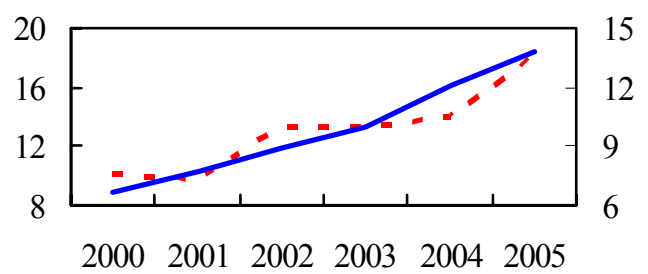

Uganda
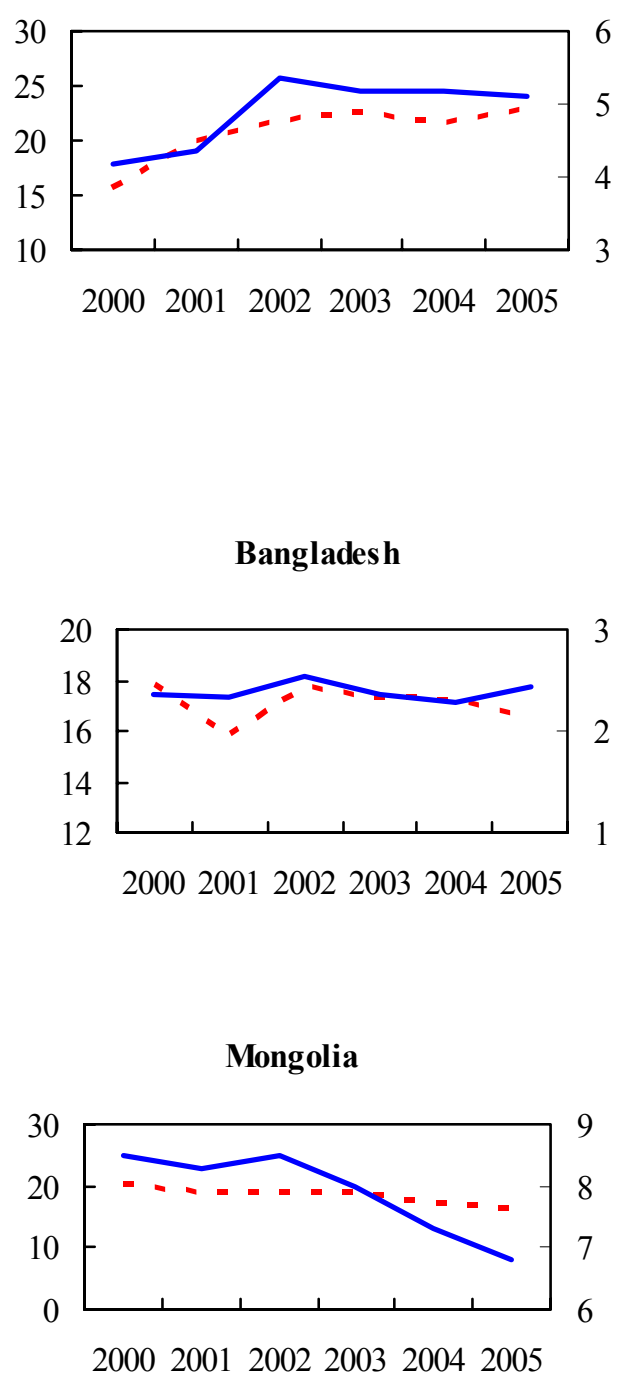

Mongolia

200020012002200320042005

Banglades h

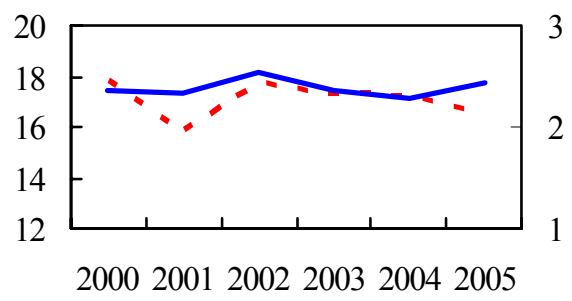

Tanzania

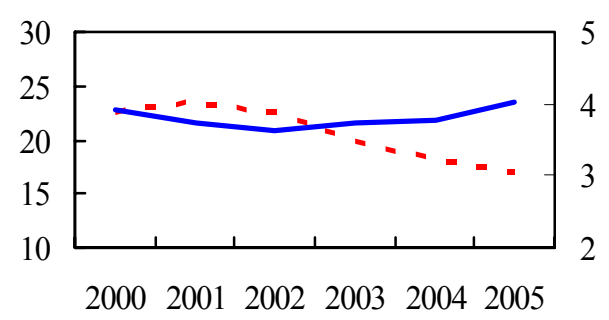

200020012002200320042005

APD

Lao, P.D.R.

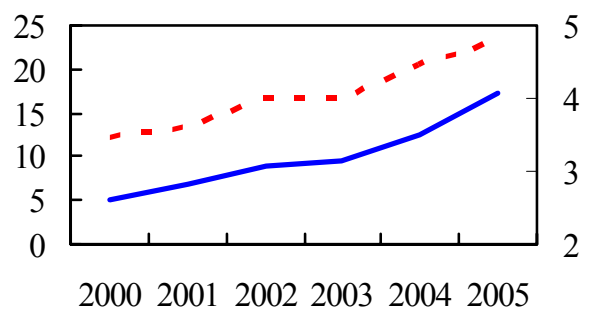

Sri Lanka

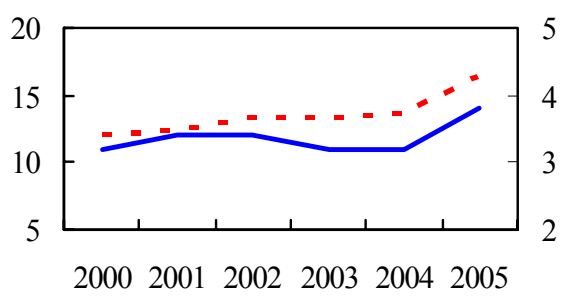




\section{EUR}

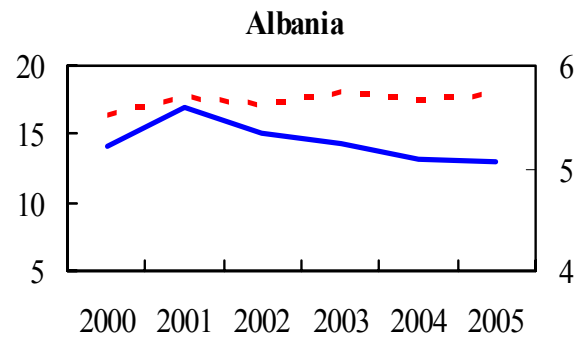

MCD
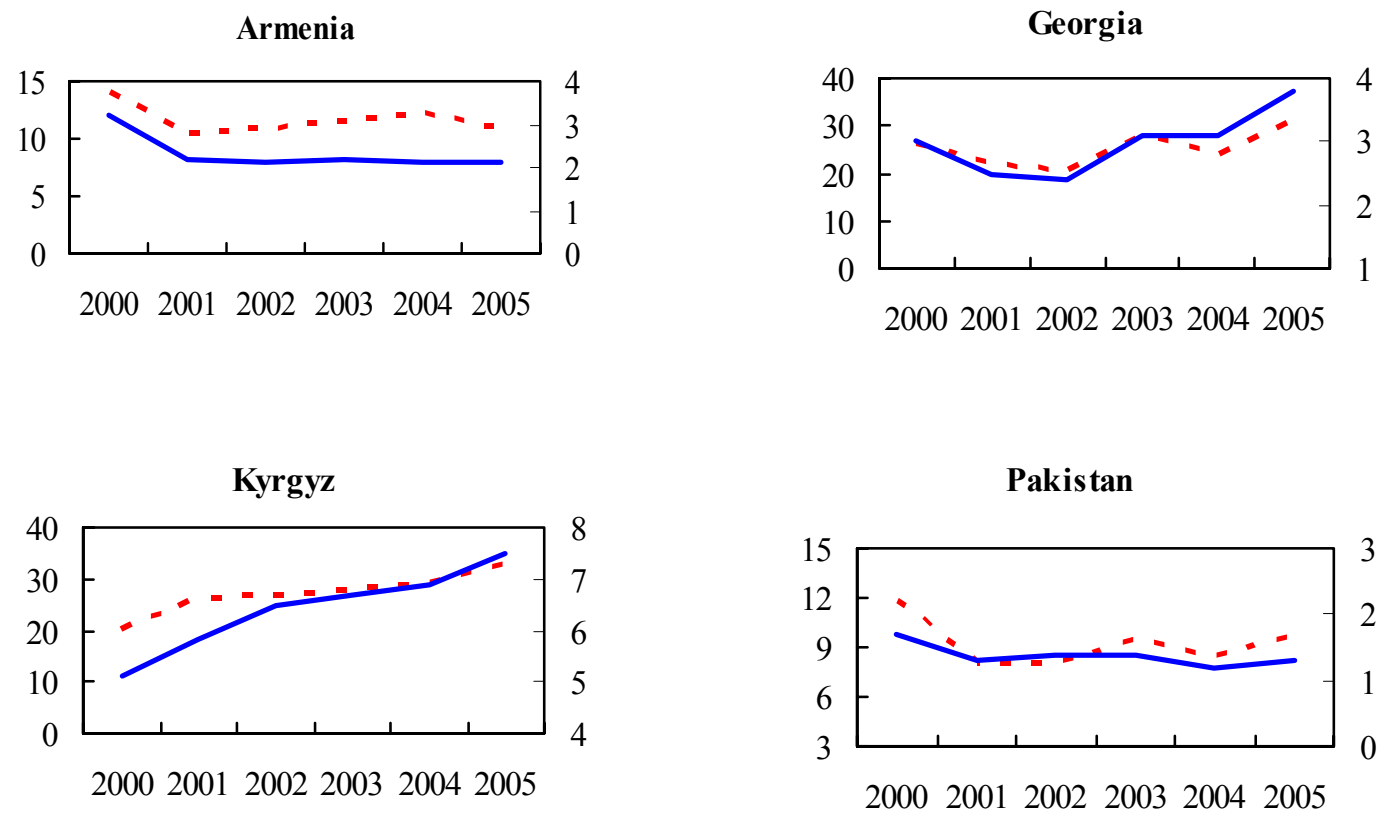

Sources: IMF's World Economic Outlook database and IMF staff estimates. 


\section{REFERENCES}

Berg, Andy, and Zia Qureshi, 2005, “The MDGs: Building Momentum," Finance and Development, Vol. 42 (September), pp. 21-23.

Center for Global Development, 2005, HIV/AIDS: Money, Bottlenecks and the Future (Washington).

Chen, Lincoln, and others, 2004, "Human Resources for Health: Overcoming the Crisis," The Lancet, Vol. 364, Issue 9449 (27 November-3 December), pp. 1984-90.

Davies, Matt, Victoria Gunnarsson, and Marijn Verhoeven, 2006, "Wage Bill Inflexibility and Performance Budgeting" (unpublished; Washington: International Monetary Fund).

Foster, Mick, 2004, "MDG-Oriented Sector and Poverty Reduction Strategies: Lessons from Experience in Health," Report Prepared for the High Level Forum on Health MDGs, Abuja.

Gupta, Sanjeev, and others, 2005, “The Macroeconomic Challenges of Scaling Up Aid to Africa," IMF Working Paper WP/05/179 (Washington: International Monetary Fund).

Heller, Peter S., 2005, "Pity the Finance Minister: Issues in Managing a Substantial Scaling Up of Aid Flows,” IMF Working Paper 05/180 (Washington: International Monetary Fund).

International Monetary Fund, 2002, Guidelines on Conditionality (Washington).

International Monetary Fund, 2005a, "The Poverty Reduction and Growth Facility (PRGF), A Factsheet," available at http://www.imf.org/external/np/exr/facts/prgf.htm.

International Monetary Fund, 2005b, "The Macroeconomics of Managing Increased Aid Inflows: Experiences of Low-Income Countries and Policy Implications" (Washington).

Stevens, M., and S. Teggemann, 2004, "Comparative Experience with Public Sector Reform in Ghana, Uganda, and Tanzania," in Building State Capacity in Africa: New Approaches, Emerging Lessons, edited by B. Levy and S. Kpundeh (Washington: World Bank).

Mattina, Todd, 2006, "Developing a Macroeconomic MDG Scenario: A Case Study of Ethiopia’s Experience” (unpublished; Washington: International Monetary Fund). 
Organization of Economic Cooperation Development-DAC, 2006, "Development Cooperation-2005 Report—Efforts and Policies of the Members of the Development Assistance Committee," OECD Journal on Development, Vol. 7 (February), pp. 1-268.

World Bank and International Monetary Fund, 2005, Global Monitoring Report (Washington: International Monetary Fund). 